\title{
ANALISIS PERILAKU PENGGUNA SISTEM INFORMASI AKADEMIK DENGAN PENDEKATAN TECHNOLOGY ACCEPTANCE MODEL (TAM) DI UNIVERSITAS SANG BUMI RUWA JURAI BANDAR LAMPUNG
}

Oleh :

Tedi Gunawan

Dosen Tetap AMIK Master Lampung

\begin{abstract}
ABSTRAK
Tujuan penelitian ini adalah untuk mengetahui bagaimana perilaku pengguna (user) dalam hal ini Mahasiswa Universitas Sang Bumi Ruwa Jurai Bandar Lampung dan operator masing-masing Fakultas dengan menggunakan pendekatan metode Technology Acceptance Model (TAM).

Pengukuran ini dilakukan dengan menggunakan beberapa variable, diantaranya persepsi kemanfaatan penggunaan / Perceived Usefulness (PU), persepsi kemudahan penggunaan / Perceived Ease of Use (PEoU), sikap penggunaan / Attitude Toward Using (ATU), kecenderungan pengguna untuk tetap menggunakan teknologi / Behavioral Intention to Use (BITU) dan kondisi nyata penggunaan sistem informasi layanan akademik/Actual System Usage (ASU).

Pengujian kesesuaian model dan hipotesis dilakukan dengan menggunakan analisis Structural Equation Model (SEM) dengan menggunakan software LISREL (LInear Structural RELationship) Versi 8.72.

Hasil penelitian menunjukan bahwa varibel kemudahan penggunaan / perceived ease of use (PEoU) berpengaruh pada persepsi kemanfaatan penggunaan / perceived usefulness (PU) dengan nilai Critical Ratio (CR) sebesar 2,15 (nilai CR yang disyaratkan yaitu $>+2,0)$, tetapi tidak berpengaruh langsung kepada sikap pengguna / Attitude Toward Using (ATU) dengan nilai CR 0,92.

Dari hasil penelitian tersebut direkomendasikan adanya perbaikan pada pengembangan Sistem Informasi Akademik ini yaitu pada menu satuan acara perkuliahan, dan Tampilan .
\end{abstract}

Kata Kunci: Technology Acceptance Model (TAM), Structural Equation Model (SEM)

\section{ANALYSIS BEHAVIOR USERS ACADEMIC INFORMATION SYSTEM WITH THE APPROACH TECHNOLOGY ACCEPTANCE A MODEL ( TAM ) AT THE UNIVERSITY OF THE THE EARTH RUWA JURAI LAMPUNG}

\author{
by: \\ Tedi Gunawan \\ Lecturer Remain AMIK MASTER Lampung
}

\begin{abstract}
The purpose of this research is to know how the complainants (user) in this case the university students the earth ruwa jurai bandar lampung and the operator each faculty by adopting both a method of Technology Acceptance A Model ( TAM ).

The measurement was done using several variable, including perception benefit the use / Perceived Usefulness (PU), perception ease the use / Perceived Ease of Use ( PEoU ), attitude the use / Attitude Toward Using ( ATU ), a tendency users to continue to use
\end{abstract}


technology / Behavioral Intention to Use ( BITU) and real conditions of the utilization of the system information services academic / Actual System Usage (ASU).

Testing conformity model and hypotheses done with using analysis Structural Equation Model (SEM) as using software LISREL (LInear Structural RELationship) Versi 8.72.

The results of the study showed that varibel ease the use / perceived ease of use (PEoU) influential on perceptual benefit the use / perceived usefulness (PU) to the value of critical ratio ( $\mathrm{CR}$ ) as much as by 2.15 ( a value CR that required that is $>+2,0$ ), but not directly influence to attitude users / Attitude Toward Using (ATU) to the value of CR 0.29.

Of this research recommended of an improvement in the development of information systems academic is in menu a unit of the event lecture, and display .

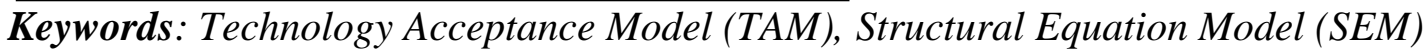

BAB I

\section{PENDAHULUAN}

\subsection{Latar Belakang}

Ada banyak model yang dikembangkan oleh para peneliti untuk mengukur penerimaan sistem informasi oleh pengguna, salah satunya adalah Technology Acceptance Model (TAM). Model TAM dikembangkan oleh Davis (1989) yang mengadaptasi model TRA (Theory of Reasoned Action). Perbedaan mendasar antara TRA dan TAM adalah penempatan sikap-sikap dari TRA, dimana TAM memperkenalkan dua variabel kunci, yaitu perceived usefulness (kebermanfaatan) dan perceived ease of use (kemudahan) yang memiliki relevancy pusat untuk memprediksi sikap penerimaan pengguna (Acceptance of IT) terhadap teknologi komputer.

Ada beberapa peneliti sebelumnya yang menggunakan Technology Acceptance Model (TAM) sebagai model pendekatan dalam penelitiannya, antara lain :

Arief Wibowo (2008), mengkaji tentang perilaku pengguna sistem informasi dengan pendekatan Technology Acceptance Model (TAM). Perasaan menerima atau menolak muncul menjadi dimensi sikap terhadap penggunaan sistem informasi. Selain sikap, diketahui ada beberapa faktor lain yang dapat mempengaruhi perilaku user terhadap penggunaan sistem informasi.

Lili Adiwibowo (2009), mengkaji tentang Perilaku Pengguna Teknologi Informasi Pada Perguruan Tinggi Berstatus BHMN dengan menggunakan pendekatan model penerimaan teknologi (Technology Acceptance Model atau TAM) yang telah dikembangkan dengan menambah variabel pengaruh sosial (sosial influence) dan kemampuan diri (self-efficacy), yang menjadi penyebab (antecendent) perilaku selain konstruk TAM lainnya 
yaitu kegunaan persepsian (perceived usefulness) dan kemudahan penggunaan persepsian (perceived ease of use) pada TAM

Rhisfan Tsani Putra (2011), mengkaji tentang penerimaan sistem informasi terhadap pengguna sesuai dengan 5 (lima) konstruk model penelitian TAM yaitu: Persepsi tentang kemudahan penggunaan (Perceived Ease Of Use), persepsi terhadap kemanfaatan (Perceived Usefulness), sikap penggunaan (Attitude Toward Using), minat perilaku untuk tetap menggunakan (Behavioral Intention To Use) dan kondisi nyata penggunaan sistem (Actual System Usage).

Berdasarkan hasil penilitian di atas, maka penulis ingin mengetahui bagaimana perilaku pengguna Sistem Aksdemik di Universitas Sang Bumi RuwaJurai dengan menggunakan Technology Acceptance Model (TAM).

Siakad adalah sistem informasi
yang didesain untuk $r$ kebutuhan
manajemen dalam upaya mendukung
fungsi-fungsi dan aktivitas yang
berhubungan dengan bidang akademik.
Semua Fakultas yang ada di Universitas
Sang Bumi Ruwa Jurai diharuskan
menggunakan aplikasi ini mulai awal
tahun 2014 atau menyongsong tahun
ajaran 2014/2015 untuk keperluan

pendataan di Fakultas masing-masing.

Universitas Sang Bumi Ruwa Jurai memiliki 4 Fakultas diantaranya Fakultas Teknik, Fakultas Ekonomi, Fakultas Hukum dan Fakultas Administrasi Negara yang wajib menggunakan aplikasi sistem informasi Akademik ini, tetapi dalam pemanfaatan sistem informasi Akademik ini belum secara maksimal digunakan untuk memenuhi kebutuhan unik informasi di Fakultas sehari-hari.

Penelitian ini menggunakan kerangka pemikiran yang mengadopsi model Technology Acceptance Model (TAM). Dengan adanya hal ini, maka penulis melakukan penelitian yaitu menganalisis perilaku pengguna terhadap penerimaan Sistem Informasi pendataan dilihat dari faktor kemudahan dan manfaat yang ada dalam sebuah teknologi sistem informasi, dengan mengangkat judul "Analisis Perilaku Pengguna Sistem Informasi Akademik Dengan Pendekatan Technology Acceptance Model (TAM) di Universitas Sang Bumi Ruwa Jurai Bandar lampung"

\subsection{Rumusan Masalah}

Dari permasalahan yang terjadi di atas didapat sebuah pertanyaan penelitian "Bagaimana perilaku dan penerimaan pengguna terhadap Sistem Informasi 
Akademik di Universitas Sang Bumi Ruwa Jurai Bandar Lampung”.

\subsection{Batasan Masalah}

Penelitian ini dilakukan untuk mengetahui bagaimana perilaku pengguna terhadap pemanfaatan Sistem Informasi Akademik di Universitas Sang Bumi Ruwa Jurai Bandar Lampung dengan pendekatan TAM (Technology Acceptance Model)". Adapun ruang lingkup yang diukur yaitu operator dan Mahasiswa dimasing-masing prodi.

\subsection{Tujuan Penelitian}

Tujuan yang ingin dicapai dalam penelitian ini adalah untuk evaluasi dan memberikan rekomendasi terhadap pengembangan Sistem Informasi Sistem Informasi Akademik di Universitas Sang Bumi Ruwa Jurai Bandar Lampung.

\subsection{Manfaat Penelitian}

Hasil penelitian ini diharapkan dapat menjadi bahan evaluasi untuk memperbaiki atau mengambil langkah selanjutnya dalam mengembangkan sistem informasi pendataan akademik yang lebih baik lagi. Manfaat dari analisis juga akan dirasakan oleh pengguna.

\subsection{Sistematika Penelitian}

Pada laporan penelitian ini terdiri dari lima bab, dengan sistematika penulisan sebagai berikut :

\section{BAB : PENDAHULUAN}

I

Bab ini terdiri dari Latar belakang masalah, perumusan masalah, ruang lingkup penelitian, tujuan penelitian, manfaat penelitian yang dilakukan, dan sistematika penulisan.

\section{BAB}

II

\section{: LANDASAN TEORI}

Bab ini berisi tentang penjelasan tentang teori-teori terkait dengan penelitian yang digunakan sebagai landasan dalam penulisan karya akhir ini, baik yang bersumber dari buku, internet, maupun jurnal-jurnal ilmiah tentang sistem informasi dan Technology Acceptance Model (TAM) yaitu penelitian tentang prilaku pengguna suatu teknologi tersebut.

\section{BAB}

III

: METODE PENELITIAN

Bab ketiga ini menyajikan metodologi yang dilakukan sebagai kerangka penelitian, metode maupun tahapan penelitian meliputi identifikasi proses dan pengumpulan data yang dimanfaatkan dalam tahap analisis. 


\section{BAB HASIL PENELITIAN DAN \\ IV PEMBAHASAN}

Bab ini menyajikan hasil penelitian, uji hipotesis dan interpretasi hasil, serta pembahasan hasil penelitian.

\section{BAB V \\ : KESIMPULAN DAN SARAN \\ Bab ini berisi kesimpulan dari hasil penelitian yang dilakukan dan saran yang ditujukan bagi peneliti selanjutnya.}

\section{BAB II}

\section{TINJAUAN PUSTAKA}

\subsection{Sistem Informasi}

Menurut Oetomo (dalam Harahap, 2010), sistem Informasi sebagai kumpulan elemen yang saling berhubungan satu sama lain yang membentuk satu kesatuan untuk mengintegrasikan data, memproses dan menyimpan serta mendistribusikan informasi.

Sedangkan menurut Indrajit (dalam Harahap, 2010), mendefinisikan sistem informasi sebagai suatu kumpulan dari komponen-komponen dalam perusahaan atau organisasi yang berhubungan dengan proses penciptaan dan pengaliran informasi.

\subsection{Sistem Informasi Akademik (SIAKAD)}

Definisi sistem adalah suatu jaringan kerja dari prosedur-prosedur yang saling berhubungan, berkumpul bersama-sama untuk melakukan suatu kegiatan atau untuk menyelesaikan suatu sasaran tertentu atau merupakan kumpulan dari elemen-elemen yang saling berinteraksi untuk mencapai suatu tujuan tersebut. Dalam hal ini, Sistem informasi memiliki tujuan untuk mengelola informasi yang berkaitan dengan sistem akademik di suatu Universitas

Sistem informasi akademik dibuat untuk memberikan informasi akademik yang dibutuhkan secara akurat dan tepat waktu. Sistem informasi akademik khususnya bertujuan untuk memberi informasi mengenai nilai dan kontrak mata kuliah, namun idealnya sistem informasi seharusnya dapat memberikan informasi yang lebih dari sekedar memberikan informasi nilai dan kontak mata kuliah saja, sistem informasi akademik dapat berisi mengenai jadwal kuliah dan jadwal ujian, SAP mata kuliah, perivikasi pembayaran uang kuliah, pendaftaran ulang dan pengisian KRS online,Pendaftaran sidang dan wisuda, forum diskusi Siswa sampai lowongan pekerjaan . Pada era sekarang ini sistem informasi akademik pada 
umumnya sudah berbasis web yang dapat diakses dimanapun dan kapan pun, dimana semua informasi yang ada dalam system dapat ditampilkan dengan menggunakan media Internet.Sistem Informasi akademik berbasis komputer sangat efisien, Efisiensi ini meliputi pengurangan jumlah kertas yang digunakan untuk pencatatan data-data, pengurangan ruangan untuk penyimpanan kertas-kertas tersebut, pengurangan tenaga perawat kertas, dan sebagainya. Selain itu,dengan sistem media elektronis ini, penulisan data secara berulang kali untuk kepentingan berbeda maupun sama dapat dihindari yang berarti menambah faktor efisiensi di atas. Dengan penerapan Sistem informasi khusus yang baik dan tepat, maka pengelolaan data-data akademik dapat menjadi sangat mudah tanpa harus meninggalkan faktor keamanannya. Dengan cara ini, pihakpihak yang berkepentingan dan berwenang terhadap data tinggal menghidupkan komputernya, lalu menggunakan program sistem informasi yang ada untuk mengelola data-data tersebut.

\subsection{Technology Acceptance Model} (TAM)

Beberapa model yang dikonstruk untuk menganalisis dan memahami faktor yang mempengaruhi diterimanya penggunaan teknologi komputer, diantaranya yang dalam berbagai literatur dan referensi hasil penelitian dibidang teknologi informasi adalah Theory of Reasoned Action (TRA), Theory of Planned Behavioral (TPB), dan Technology Acceptance Model (TAM) yang diperkenalkan pertama kali oleh Davis pada tahun 1989. TAM merupakan hasil pengembangan dari Theory of Reasoned Action (TRA), yaitu teori tindakan yang beralasan dengan satu premis bahwa reaksi dan persepsi seseorang terhadap sesuatu hal, akan menentukan sikap dan perilaku orang tersebut (Davis, 1989).

Reaksi dan persepsi pengguna Teknologi Informasi (TI) akan mempengaruhi sikapnya dalam penerimaan terhadap teknologi tersebut. Salah satu faktor yang dapat mempengaruhinya adalah persepsi pengguna terhadap kemanfaatan dan kemudahan penggunaan TI sebagai suatu tindakan yang beralasan dalam konteks pengguna teknologi, sehingga alasan seseorang dalam melihat manfaat dan kemudahan penggunaan TI menjadikan tindakan atau perilaku orang tersebut sebagai tolok ukur dalam penerimaan sebuah teknologi. 
Teori-teori yang terkait dengan faktor seorang individu dalam penggunaan teknologi informasi diantaranya adalah teori perilaku terencana (Theory of Planned BehavioralTPB), teori tindakan beralasan (Theory of Reason Action- TRA), Innovation Diffusion Theory (IDT), dan model penerimaan teknologi (Technology Acceptance Model- TAM). Perbandingan berbagai macam teori tersebut dapat dilihat pada table 2.1 berikut ini :

Tabel 2.1. Model dan Teori Penerimaan Individu

\begin{tabular}{|c|c|c|}
\hline MODEL & $\begin{array}{c}\text { CORE } \\
\text { CONSTRUCTIO } \\
\text { N }\end{array}$ & DEFINITION \\
\hline \multicolumn{3}{|c|}{ Theory of Reasoned Action (TRA) } \\
\hline \multirow{2}{*}{$\begin{array}{l}\text { Model teori TRA } \\
\text { yang dikembangkan } \\
\text { oleh Martin Fishbein } \\
\text { dan Icek Ajzen, } \\
\text { merupakan model teori } \\
\text { psikologi sosial yang } \\
\text { secara fundamental } \\
\text { menerangkan faktor - } \\
\text { faktor yang } \\
\text { mendorong perilaku } \\
\text { manusia. }\end{array}$} & $\begin{array}{l}\text { sikap terhadap } \\
\text { tingkah laku / } \\
\text { Attitude Toward } \\
\text { Behavior }\end{array}$ & $\begin{array}{l}\text { Perasaan positif atau } \\
\text { negatif individu } \\
\text { (pengaruh evaluatif ) } \\
\text { tentang perilaku } \\
\text { sasaran" (Fishbein } \\
\text { dan Ajzen 1975, p. } \\
\text { 216). }\end{array}$ \\
\hline & Subjective Norm & $\begin{array}{l}\text { Persepsi bahwa } \\
\text { kebanyakan orang } \\
\text { berpikir dia harus } \\
\text { atau tidak harus } \\
\text { melakukan perilaku } \\
\text { yang tersebut" } \\
\text { (Fishbein dan Ajzen } \\
\text { 1975, p. 302). }\end{array}$ \\
\hline \multicolumn{3}{|c|}{ Theory of Planned Behavior (TPB) } \\
\hline $\begin{array}{l}\text { Teori ini adalah } \\
\text { pengembangan dan } \\
\text { penyempurnaan dari } \\
\text { Theory of Reasoned } \\
\text { Action (TRA). } \\
\text { Perbedaan mendasar } \\
\text { model teori ini }\end{array}$ & $\begin{array}{l}\text { Sikap terhadap } \\
\text { tingkah laku / } \\
\text { Attitude Toward } \\
\text { Behavior }\end{array}$ & Diadaptasi dari TRA \\
\hline
\end{tabular}

\begin{tabular}{|c|c|c|}
\hline MODEL & $\begin{array}{c}\text { CORE } \\
\text { CONSTRUCTIO } \\
\text { N }\end{array}$ & DEFINITION \\
\hline $\begin{array}{l}\text { dengan TRA adalah } \\
\text { adanya tambahan satu } \\
\text { elemen dalam model } \\
\text { konstruksi yang disebut } \\
\text { sebagai persepsi } \\
\text { terhadap kendali } \\
\text { perilaku seseorang } \\
\text { (Perceived Behavioral } \\
\text { Control, PBC) }\end{array}$ & $\begin{array}{l}\text { Persepsi Kontrol } \\
\text { Perilaku }\end{array}$ & $\begin{array}{l}\text { Persepsi kemudahan } \\
\text { atau kesulitan } \\
\text { melakukan perilaku } \\
\text { (Ajzen 1991, p.188). }\end{array}$ \\
\hline \multicolumn{3}{|c|}{ Technology Acceptance Model (TAM) } \\
\hline $\begin{array}{l}\text { Technology } \\
\text { Acceptance Model } \\
\text { (TAM) yang pertama } \\
\text { kali diperkenalkan oleh } \\
\text { Fred D. Davis (1989), } \\
\text { adalah adaptasi dari } \\
\text { TRA yang dibuat } \\
\text { khusus untuk } \\
\text { pemodelan penerimaan } \\
\text { pengguna terhadap } \\
\text { sistem informasi. }\end{array}$ & $\begin{array}{l}\text { Persepsi Kegunaan } \\
\text { / Perceived } \\
\text { Usefulness }\end{array}$ & $\begin{array}{l}\text { Sejauh mana } \\
\text { seseorang percaya } \\
\text { bahwa } \\
\text { menggunakan sistem } \\
\text { tertentu akan } \\
\text { meningkatkan } \\
\text { kinerja } \\
\text { pekerjaannya" } \\
\text { (Davis 1989, p. } \\
\text { 320). }\end{array}$ \\
\hline $\begin{array}{l}\text { tujuan utama TAM } \\
\text { adalah memberikan } \\
\text { dasar untuk } \\
\text { penelusuran pengaruh } \\
\text { faktor-faktor eksternal } \\
\text { terhadap kepercayaan, } \\
\text { sikap, dan tujuan } \\
\text { pengguna. TAM } \\
\text { menganggan bahwa }\end{array}$ & $\begin{array}{l}\text { Persepsi } \\
\text { kemudahan } \\
\text { penggunaan / } \\
\text { Perceived Ease of } \\
\text { Use }\end{array}$ & $\begin{array}{l}\text { Sejauh mana } \\
\text { seseorang percaya } \\
\text { bahwa } \\
\text { menggunakan sistem } \\
\text { tertentu akan bebas } \\
\text { dari upaya" (Davis } \\
\text { 1989, p. 320). }\end{array}$ \\
\hline $\begin{array}{l}\text { dua keyakinan } \\
\text { individual, yaitu } \\
\text { persepsi manfaat } \\
\text { (Perceived Usefullness, } \\
\text { disingkat Perceived } \\
\text { Usefullness) dan } \\
\text { persepsi kemudahan } \\
\text { penggunaan (Perceived } \\
\text { Ease of Use, disingkat } \\
\text { PEoU), adalah } \\
\text { pengaruh utama untuk } \\
\text { perilaku penerimaan } \\
\text { komputer. }\end{array}$ & $\begin{array}{l}\text { Norma Subjektif } \\
\text { (Subjective Norm) }\end{array}$ & $\begin{array}{l}\text { Diadaptasi dari } \\
\text { TRA/TPB }\end{array}$ \\
\hline
\end{tabular}

\section{Davis (1989) membangun}

Technology Acceptance Model (TAM) untuk menjelaskan dan memprediksi penggunaan sukarela proses penerimaan sistem informasi baru pengguna di dalam 
lingkungan kerja. TAM diadaptasi dari Theory fo Reasoned Action (TRA) Fishbein \& Ajzen (1991) dengan menggantikan faltor-faktor penentu sikap (attitude) dengan seperangkat set yang terdiri atas dua variabel, yaitu Perceived Usefullness (persepsi kegunaan/ manfaat) dan Perceived Ease of Use (persepsi kemudahan penggunaan). Meskipun kedua model TRA dan TAM mampu memprediksi minat dan pemakaian dalam teknologi informasi dengan memuaskan, TAM diketahui lebih simpel dan mudah digunakan namun lebih kuat dalam memodelkan faktor-faktor penentu penerimaan teknologi komputer oleh pemakai (Igbaria, 1993).

Technology Acceptance Model (TAM) dikembangkan pertama kali oleh Davis pada tahun 1989. Sampai saat ini TAM merupakan model yang paling banyak digunaka dalam memprediksi penerimaan atas teknologi informasi (Gefen,2002) dan telah terbukti menjadi model teoritis yang sangat membantu memahami perilaku pengguna dalam mengimplementasikan suatu sistem informasi.

Model TAM yang dikembangkan dari teori psikologis, menjelaskan perilaku pengguna komputer yaitu berlandaskan pada kepercayaan (belief), sikap (attitude), keinginan (intention), dan hubungan perilaku (user behaviour relationship). Tujuan model ini untuk menjelaskan faktor-faktor utama dari perilaku pengguna terhadap penerimaan pengguna teknologi. Secara lebih rinci menjelaskan tentang penerimaan Teknologi Informasi dengan dimensi tertentu yang dapat mempengaruhi diterimanya Teknologi Informasi oleh pengguna (user). Model ini menempatkan faktor sikap dari tiap-tiap perilaku pengguna dengan dua variabel kemudahan penggunaan (Ease of Use ) dan kemanfaatan (Usefulness). Kedua variabel ini dapat menjelaskan aspek keperilakuan pengguna. Kesimpulannya adalah model TAM dapat menjelaskan bahwa persepsi pengguna akan menentukan sikapnya dalam kemanfaatan penggunaan Teknologi Informasi. Model ini secara lebih rinci lebih jelas menggambarkan bahwa penerimaan penggunaan Teknologi Informasi dipengaruhi oleh pemanfaatan (Usefulness) dan kemudahan penggunaan (Ease of Use) 


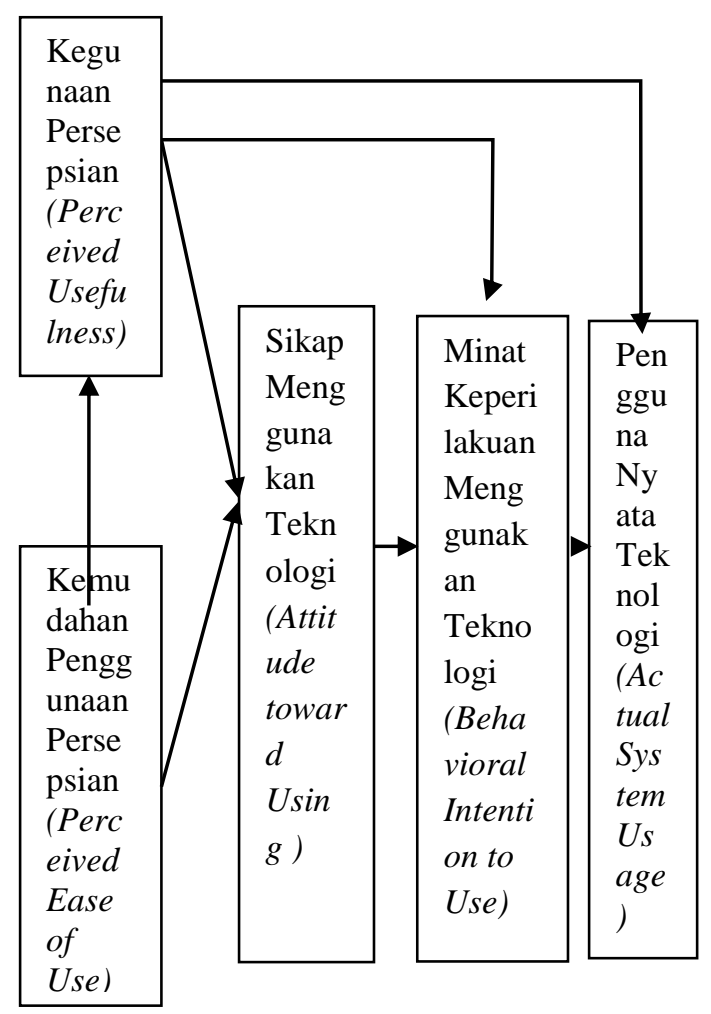

Gambar 2.1. Model Technology

Acceptance Model (Davis, 1989)

Model dasar dari pembentukan sikap yang mempengaruhi perilaku seseorang, TAM menggambarkan hubungan antar variabel (Davis, 1989) ;

\section{Perceived Ease of Use (PEoU)}

Menyatakan tingkat kepercayaan bahwa teknologi baru akan mudah untuk dipakai dan terbebas dari usaha.

2. Perceived Usefulness (PU)

Menyatakan tingkat kepercayaan bahwa penggunaan teknologi baru akan meningkatkan pencapaian.

3. Attitude Toward Using (ATU)

Menyatakan sikap pengguna (user) ke arah menggunakan teknologi baru.
4. Behavioral Intention to Use (ITU)

Menyatakan pengguna (user) benarbenar mempunyai minat menggunakan teknologi baru secara nyata karena merasakan manfaatnya

5. Actual System Usage (ASU)

Menyatakan pengguna (user) benarbenar menggunakan teknologi baru secara nyata karena merasakan manfaatnya.

Untuk mengungkap mengenai saling hubungan antara persepsi terhadap manfaat dan persepsi kemudahan menggunakan IT ini, Davis et.al., (1989) melakukan riset dengan cara menyajikan masing-masing 6 item, seperti pada tabel berikut :

Tabel 2.2 Faktor-faktor yang mempengaruhi penerimaan terhadap IT

\begin{tabular}{|c|l|l|}
\hline NO & \multicolumn{1}{|c|}{$\begin{array}{c}\text { Kegunaan } \\
\text { (usefulness) }\end{array}$} & $\begin{array}{l}\text { Kemudahan (easy } \\
\text { of use) }\end{array}$ \\
\hline 1 & $\begin{array}{l}\text { Pemenuhan } \\
\text { kebutuhan } \\
\text { informasi }\end{array}$ & $\begin{array}{l}\text { Kemudahan untuk } \\
\text { diakses }\end{array}$ \\
\hline 2 & $\begin{array}{l}\text { Meningkatkan } \\
\text { efektififitas }\end{array}$ & Fleksibilitas \\
\hline 3 & $\begin{array}{l}\text { Meningkatkan } \\
\text { kinerja }\end{array}$ & $\begin{array}{l}\text { Kemudahan untuk } \\
\text { dipahami }\end{array}$ \\
\hline 4 & $\begin{array}{l}\text { Meningkatkan } \\
\text { efisiensi }\end{array}$ & $\begin{array}{l}\text { Kemudahan untuk } \\
\text { digunakan }\end{array}$ \\
\hline
\end{tabular}

Sumber : Davis et.al (1989) 


\subsection{Persepsi}

Manusia sebagai mahluk sosial yang sekaligus juga mahluk individual, maka terdapat perbedaan antara individu yang satu dengan yang lainnya. Adanya perbedaan inilah yang antara lain menyebabkan mengapa seseorang menyenangi suatu obyek, sedangkan orang lain tidak senang. Hal ini tergantung bagaimana individu menanggapi obyek obyek tersebut dengan persepsinya. Pada kenyataannyasebagian besar sikap, tingkah laku dan penyesuaian ditentukan oleh persepsinya.

Dalam kamus besar bahasa Indonesia istilah persepsi diartikan sama dengan tanggapan. Oleh Poerwadarminta, menjelaskan istilah persepsi diartikan sebagai suatu yang diserap, diterima dengan cara panca indra, seperti melihat, mendengar, merasai ataupun sering diterjemahkan sebagai bayangan dalam angan-angan, pendapat, pandangan, sebutan atau reaksi yang pada hakikatnya mengarah kepada apa yang ditanggapinya melalui panca indra terbayang dalam angan-angan (Poerwadarminta, 1976).

\subsubsection{Perceived Ease of Use (Persepsi kemudahan penggunaan)}

Pengertian Perceived Ease of Use menurut Davis (1989) adalah "the degree to with a person believes that using a particular system would be free of effoti". Persepsi kemudahan penggunaan mencerminkan bahwa usaha merupakan sumber daya yang terbatas bagi seseorang yang akan mengalokasikan untuk berbagai kegiatan. Yang paling penting bagi pengguna adalah jumlah usaha yang dia keluarkan untuk dikeluarkan dalam menggunakan suatu sistem. Segala sesuatu yang sama, sistem yang mudah digunakan akan meningkatkan niat untuk menggunakan sebagai kebalikan dari suatu sistem yang lebih mudah digunakan (Davis, 1989).

Dapat diartikan suatu sikap atau pandangan yang dimiliki seorang pengguna yang memiliki keyakinan bahwa teknologi dan sistem informasi mudah dipahami dan digunakan. Intensitas penggunaan dan interaksi antar pengguna dengan sistem dapat menunjukkan kemudahan dalam penggunaan. Sistem yang digunakan menunjukkan sistem tersebut lebih dikenal, lebih mudah dioperasikan, dan lebih mudah digunakan.

Adapun beberapa indikator kemudahan penggunaan :

a. Sistem informasi sangat mudah dioperasikan

b. Menggunakan sistem tidaklah menyulitkan pengguna 
c. Pengguna merasa yakin bahwa mudah untuk mengerjakan apa yang diperlukan dengan sistem yang tersedia

d. Pengguna merasa yakin bahwa belajar menggunakan teknologi tidaklah memerlukan usaha keras.

\subsubsection{Perceived Usefulness (Persepsi manfaat)}

Pengertian Perceived Usefulness menurut Davis (1989) adalah "the degree to which a person believes that using a particular system would enhance his or her job performance. Perceived Usefullness dapat diartikan suatu sikap atau pandangan seorang pengguna yang percaya bahwa dengan menggunakan sistem aplikasi dapat meningkatkan kinerja sehingga individu tersebut dapat melaksanakan tugas dan pekerjaan mereka lebih baik lagi.

Kegunaan teknologi informasi terbagi dalam dua kategori (Chin, 1991) yaitu :

a. Kegunaan dengan estimasi satu faktor, meliputi :

1. Menjadikan pekerjaan lebih mudah

2. Bermanfaat

3. Menambah produktifitas

4. Mempertinggi efektivitas

5. Mengembangkan kinerja b. Kegunaan dengan estimasi dua faktor, meliputi :

1. Kegunaan meliputi dimensi : pekerjaan menjadi lebih mudah, bermanfaat dan menambah produktifitas

2. Efektivitas meliputi dimensi : mempertinggi efektivitas dan mengembangkan kinerja pekerjaan

\subsubsection{Attitude Toward Using (Sikap dalam pemanfaatan TI)}

Attitude menyatakan sikap pengguna untuk melihat penerimaan pengguna terhadap teknologi informasi maupun kamauan untuk memakai teknologi informasi. Attitude Toward Using dalam TAM dikonsepkan sebagai sikap terhadap penggunaan sistem yang berbentuk penerimaan atau penolakan sebagai akibat dari bilamana seseorang menggunakan suatu teknologi dalam pekerjaannya (Davis, 1989). Penelitian ini menyatakan bahwa faktor sikap (Attitude) sebagai salah satu aspek yang mempengaruhi perilaku individual. Sikap seseorang terdiri atas unsur kognitif cara pandang (cognitive), afektif (affective), dan komponen-komponen yang berkaitan dengan perilaku (behavioral components). 


\subsubsection{Behavioral Intention to \\ Use (Sikap untuk tetap menggunakan sistem)}

Seseorang akan mempunyai niat untuk selalu menggunakan suatu sistem informasi atau teknologi informasi. Behavioral Intention to Use adalah kecenderungan perilaku untuk tetap menggunakan suatu teknologi.

\subsubsection{Actual System Usage (Pemakaian}

\section{Sistem Nyata)}

Seseorang akan merasa puas menggunakan sistem jika sistem tersebut mudah digunakan dan akan meningkatkan produktifitas mereka. Actual Usage adalah kondisi nyata penggunaan sistem. Dikonsepkan dalam bentuk pengukuran terhadap frekuensi dan durasi waktu penggunaan teknologi (Davis, 1989). Seseorang akan puas menggunakan sistem jika mereka meyakini bahwa sistem tersebut mudah digunakan dan akan meningkatkan produktifitas mereka, yang tercermin dari kondisi nyata penggunaan.

\subsection{Kerangka Pikir Penelitian}

Penelitian ini menganalisis tentang perilaku pengguna sistem informasi yang digunakan di Universitas Sang Bumi Ruwa Jurai Bandar Lampung, dimana sikap pengguna (user) dipengaruhi oleh dua faktor yaitu faktor persepsi atas kemudahan (Perceived Ease of Use (PEoU)) dan faktor persepsi atas kemanfaatan (Perceived Usefulness (PU) dengan model TAM. Pengaruh positif dari kedua faktor tersebut mengartikan bahwa kedua persepsi tersebut akan mempengaruhi sikap pengguna (user).

Tabel 2.3. Kerangka Konsep Kisi-kisi Penelitian

\begin{tabular}{|c|c|c|}
\hline Variabel & Dimensi & Referensi \\
\hline \multirow{4}{*}{$\begin{array}{c}\text { Perceived Ease of } \\
\text { Use }\end{array}$} & $\begin{array}{l}\text { Kemudahan untuk } \\
\text { diakses }\end{array}$ & \multirow{4}{*}{ Davis (1989) } \\
\hline & Fleksibilitas & \\
\hline & $\begin{array}{l}\text { Kemudahan untuk } \\
\text { dipahami }\end{array}$ & \\
\hline & $\begin{array}{l}\text { Kemudahan untuk } \\
\text { digunakan }\end{array}$ & \\
\hline \multirow{4}{*}{$\begin{array}{l}\text { Perceived } \\
\text { Usefulness }\end{array}$} & $\begin{array}{l}\text { Pemenuhan } \\
\text { kebutuhan informasi }\end{array}$ & \multirow{4}{*}{$\begin{array}{c}\text { Davis (1989); } \\
\text { Chin (1991) }\end{array}$} \\
\hline & $\begin{array}{l}\text { Meningkatkan } \\
\text { efektififitas }\end{array}$ & \\
\hline & Meningkatkan kinerja & \\
\hline & $\begin{array}{l}\text { Meningkatkan } \\
\text { efisiensi }\end{array}$ & \\
\hline \multirow{4}{*}{$\begin{array}{l}\text { Attitude Toward } \\
\text { Using }\end{array}$} & $\begin{array}{l}\text { Kenyamanan } \\
\text { berinteraksi }\end{array}$ & \multirow{4}{*}{ Davis (1989) } \\
\hline & Senang menggunakan & \\
\hline & Kepuasan & \\
\hline & $\begin{array}{l}\text { Menumbuhkan } \\
\text { motivasi }\end{array}$ & \\
\hline \multirow{4}{*}{$\begin{array}{c}\text { Behavioral Intention } \\
\text { to Use }\end{array}$} & $\begin{array}{l}\text { Berupaya } \\
\text { memberikan } \\
\text { informasi }\end{array}$ & \multirow{4}{*}{ Davis (1989) } \\
\hline & $\begin{array}{l}\text { Berupaya } \\
\text { menggunakan }\end{array}$ & \\
\hline & $\begin{array}{l}\text { Berupaya menjaga } \\
\text { informasi }\end{array}$ & \\
\hline & $\begin{array}{l}\text { Pemanfaatan } \\
\text { Teknologi }\end{array}$ & \\
\hline \multirow{4}{*}{ Actual System Usage } & $\begin{array}{l}\text { Frekuensi } \\
\text { penggunaan }\end{array}$ & \multirow{4}{*}{ Davis (1989) } \\
\hline & Kepuasan pengguna & \\
\hline & Prestice pengguna & \\
\hline & Informatif & \\
\hline
\end{tabular}




\subsection{Perumusan Hipotesis}

Pengembangan hipotesis

berdasarkan konstruk yang ada

adalah sebagai berikut :

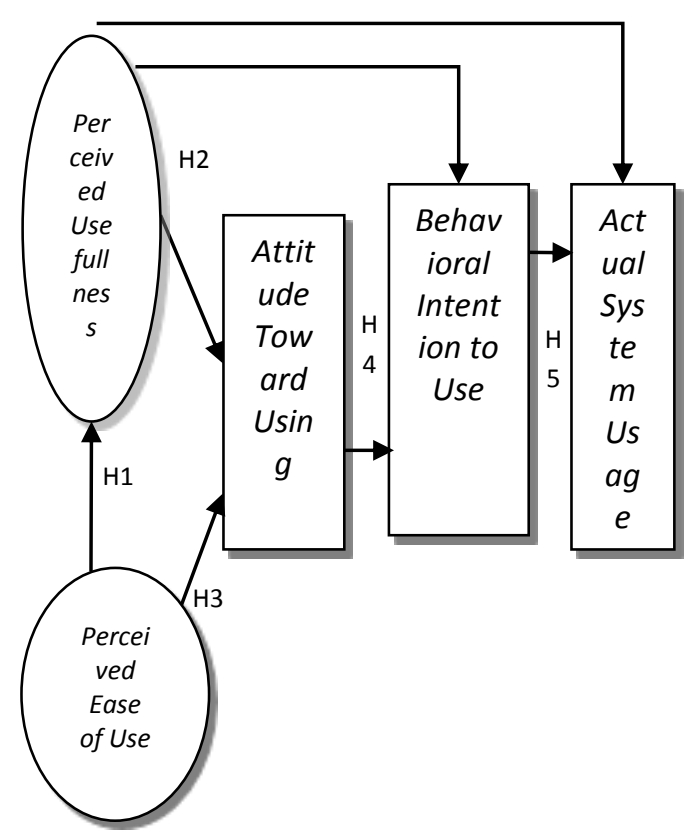

Gambar 2.2. Gambar hipotesis

berdasarkan konstruk

a. Diduga bahwa Persepsi Kemudahan (Perceived Ease of Use) berpengaruh positif terhadap persepsi kegunaan (Perceived Usefullness).

b. Diduga bahwa Persepsi Kegunaan (Perceived Usefullness) berpengaruh positif terhadap sikap pengguna (Attitude Toward Using).

c. Diduga bahwa Peserpsi Kemudahan (Perceived Ease of Use) berpengaruh positif terhadap sikap pengguna (Attitude Toward Using).

d. Diduga bahwa Sikap pengguna (Attitude Toward Using) berpengaruh positif terhadap minat pengguna teknologi (Behavioral Intention to Use).

e. Diduga bahwa Minat penggunaan (Behavioral Intention to Use) berpengaruh positif terhadap pengguna nyata (Actual System Usage).

\subsection{Skala Likert}

Skala Likert digunakan untuk mengukur sikap, pendapat, dan persepsi seseorang atau sekelompok orang tentang fenomena sosial. Dalam penelitian, fenomena sosial ini telah ditetapkan secara spesifik oleh peneliti, yang selanjutnya sebagai variabel penelitian.

Dengan skala Likert, maka variabel yang akan diukur dijabarkan menjadi indikator variabel. Kemudian indikator tersebut dijadikan sebagai titik tolak untuk menyusun item-item instrument yang dapat berupa pernyataan atau pertanyaan. Untuk keperluan analisis, maka jawaban itu dapat diberi skor, misalnya :
a. Sangat Tidak Setuju (STS) 1
b. Tidak Setuju (TS) 2
c. Kurang Setuju (KS) 3
d. Setuju (S) 4
e. Sangat Setuju (SS)

\subsection{Uji Validitas dan Reliabilitas}

Pengujian validitas dan reliabilitas terhadap instrumen penelitian perlu dilakukan agar data yang diperoleh 
benar-benar valid dan reliabel. Validitas adalah suatu ukuran yang menunjukkan tingkat kevalidan atau kesahian suatu instrumen yang bersangkutan mampu mengukur apa yang diukur, sedangkan uji reliabilitas bertujuan untuk mengukur keandalan alat ukur dengan cara memberikan skor yang relatif sama pada seorang responden, walaupun responden mengerjakannya dalam waktu yang berbeda.

Pengujian tingkat validitas dan reliabilitas dihitung dengan alat bantu komputer. Menurut Nunally (1969) dalam Ghozali (2005), suatu konstruk atau variabel dikatakan reliabel, jika memberikan nilai cronbach alpha $>0,60$. Sedangkan validitas dalam penelitian ini diukur dengan digunakan Coeficient corelation pearson yaitu dengan menghitung korelasi antara skor masingmasing butir pertanyaan dengan total skor (Ghozali, 2005).

\subsubsection{Uji Validitas}

Instrumen yang valid berarti alat ukur yang digunakan untuk mendapatkan data (mengukur) itu valid. Valid berarti instrumen tersebut dapat digunakan untuk mengukur apa yang hendak diukur. Uji validitas yang dilakukan bertujuan untuk menguji sejauh mana item kuesioner yang valid dan mana yang tidak valid.
Hal ini dilakukan dengan mencari korelasi setiap item pernyataan dengan skor total pernyataan untuk hasil jawaban responden yang mempunyai skala pengukuran ordinal.

Besarnya koefisien korelasi diinterpretasikan dengan menggunakan Tabel 2.4 dibawah ini :

Tabel 2.4. Interpretasi Koefisien Korelasi

\begin{tabular}{|c|c|}
\hline $\begin{array}{c}\text { Interval } \\
\text { Koefisien }\end{array}$ & Tingkat Hubungan \\
\hline $0,00-0,199$ & Sangat rendah \\
\hline $0,20-0,399$ & Rendah \\
\hline $0,40-0,599$ & Sedang \\
\hline $0,60-0,799$ & Kuat \\
\hline $0,80-1,000$ & Sangat kuat \\
\hline
\end{tabular}

Sumber : Sugiyono (2008)

Keputusan pengujian validitas menggunakan taraf signifikansi dengan kriteria sebagai berikut :

a. Nilai $\mathrm{t}$ dibandingkan dengan harga ttabel dengan $\mathrm{dk}=\mathrm{n}-2$ dan taraf signifikansi $\alpha=0,01$

b. Jika thitung > ttabel maka soal tersebut valid.

c. Jika thitung < ttabel maka soal tersebut tidak valid.

Pengujian validitas diperlukan untuk mengetahui apakah instrumen yang akan digunakan untuk mencari data primer dalam sebuah penelitian dapat digunakan untuk mengukur apa yang seharusnya terukur. 


\subsubsection{Uji Reliabilitas}

Uji reliabilitas dilakukan untuk mendapatkan tingkat ketepatan alat pengumpulan data yang digunakan. Reliabilitas menunjuk pada suatu pengertian bahwa suatu instrumen cukup dapat dipercaya untuk digunakan sebagai alat pengumpul data, karena instrument tersebut sudah baik. Instrument yang sudah dipercaya, yang realibel akan menghasilkan data yang dapat dipercaya juga.

Menurut Sugiyono

(2008)

"Reliabilitas adalah pengukuran yang berkali-kali menghasilkan data yang sama atau konsisten". Sedangkan menurut Arikunto (2009) “Reliabilitas menunjuk pada satu pengertian bahwa sesuatu instrument cukup dapat dipercaya untuk dapat digunakan sebagai alat pengumpul data karena instrument tersebut sudah baik. Reliabilitas menunjuk pada tingkat keterandalan sesuatu".

\section{BAB III METEDOLOGI PENELITIAN}

\subsection{Desain Penelitian}

Desain penelitian merupakan rancangan penelitian yang digunakan sebagai pedoman dalam melakukan proses penelitian. Desain penelitian akan berguna bagi semua pihak yang terlibat dalam proses penelitian, karena langkah dalam melakukan penelitian mengacu kepada desain penelitian yang telah dibuat. Berikut ini adalah desain penelitian yang akan dilakukan :

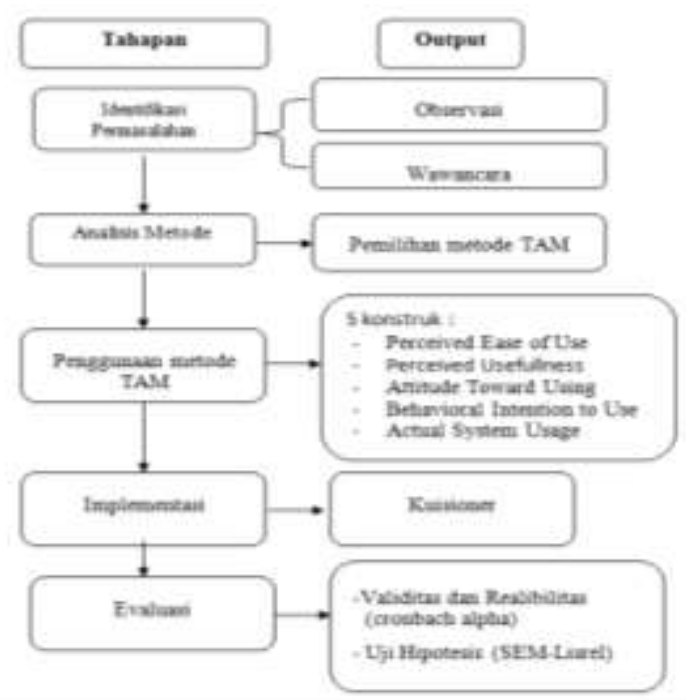

Gambar 3.1. Desain alur penelitian

\subsection{Identifikasi Permasalahan}

Permasalahan dalam penelitian ini adalah bahwa dari observasi dan wawancara yang dilakukan menunjukan penerapan sistem informasi Akademik di Universitas Sang Bumi Ruwa Jurai belum dilaksanakan secara maksimal artinya belum menyetuh pada kewajiban untuk menggunakan sistem informasi ini sebagai alat harian yang mampu menjawab kebutuhan yang unik di masing-masing fakultas. Sehingga perlu dilakukan sebuah kajian tentang penerimaan pengguna terhadap sistem informasi Akademik ini. 


\subsection{Analisis Metode}

Ada beberapa model yang digunakan untuk menganalis prilaku pengguna sistem informasi antara lain : Theory of Reasoned Action (TRA) yang dikembangkan oleh Ajzen dan Fishbein, model ini memiliki keterbatasan utama, yaitu hanya dimaksudkan untuk menjelaskan perilaku pengguna secara sukarela bukan perilaku pengguna yang diwajibkan, sehingga model ini kurang mengena jika digunakan untuk memprediksi perilaku yang spontan, kebiasaan, dan diwajibkan.

Model yang lain adalah Technology Acceptance Model (TAM), diperkenalkan pertama kali oleh Davis pada tahun 1989. TAM dibuat khusus untuk pemodelan adopsi pengguna system informasi. Menurut Davis (1989), tujuan utama TAM adalah untuk mendirikan dasar penelusuran pengaruh faktor eksternal terhadap kepercayaan, sikap (personalisasi), dan tujuan pengguna komputer. TAM menganggap bahwa dua keyakinan variabel perilaku utama dalam mengadopsi sisitem informasi, yaitu persepsi pengguna terhadap manfaat (perceived usefulness) dan persepsi pengguna terhadap penggunaan (perceived ease of use). Perceived usefulness diartikan sebagai tingkat di mana seseorang percaya bahwa menggunakan system tertentu dapat meningkatkan kinerjanya, dan perceived ease of use diartikan sebagai tingkat dimana seseorang percaya bahwa menggunakan system tidak diperlukan usaha apapun (free of effort). perceived ease of use juga berpengaruh pada perceived usefulness yang dapat diartikan bahwa jika seseorang merasa system tersebut mudah digunakan maka system tersebut berguna bagi mereka.

Penggunaan model TAM didasarkan pada pendapat Venkatesh dan Davis (2000) yang menyatakan bahwa sejauh ini TAM merupakan sebuah konsep yang dianggap paling baik dalam menjelaskan perilaku user terhadap sistem teknologi informasi baru. Menurut Venkatesh dan Davis (2000) TAM secara empiris terbukti menjelaskan $40 \%$ usage intensions dan behavior.

Secara teoritis dan praktis TAM merupakan model yang dianggap paling tepat dalam menjelaskan bagaimana user menerima sebuah sistem. TAM menyatakan bahwa behavioral intension to use ditentukan oleh dua keyakinan yaitu: pertama, perceived usefulness yang didefinisikan sebagai sejauh mana seseorang yakin bahwa 
menggunakan sistem akan meningkatkan kinerjanya. Kedua, perceived ease of use yang didefinisikan sebagai sejauh mana seseorang yakin bahwa penggunaan sistem adalah mudah. TAM juga menyatakan bahwa dampak variabel-variabel eksternal seperti (karakteristik sistem, proses pengembangan dan pelatihan) terhadap intension to use adalah dimediasi oleh perceived of usefulness dan perceived ease of use. Konsep TAM juga menyatakan bahwa perceived usefulness dipengaruhi oleh perceived ease of used.

\subsection{Penggunaan Technology \\ Acceptance Model (TAM)}

Untuk menyamakan persepsi berkaitan dengan variabel-variabel yang digunakan, peneliti perlu untuk mendefinisikan operasionalisasi variabelvariabel dalam penelitian ini secara singkat telah diungkapkan dalam latar belakang dan tinjauan pustaka. Hal ini dimaksudkan juga untuk mempermudah penentuan indikator-indikator sekaligus penentuan instrumen pengukuran variabel.

Variabel-variabel yang digunakan dalam penelitian ini adalah sebagai berikut :

a. Persepsi Kemudahan Penggunaan $\left(\mathrm{X}_{1}\right)$
Kemudahan penggunaan (ease of use) didefinisikan sebagai sejauhmana seseorang percaya bahwa dengan menggunakan suatu teknologi akan bebas dari usaha (Jogiyanto, 2007).

b. Persepsi Kegunaan/ Kebermanfaatan $\left(\mathrm{X}_{2}\right)$

Kegunaan/ Kebermanfaatan (usefulness) didefinisikan sebagai sejauhmana seseorang percaya bahwa menggunakan suatu teknologi akan meningkatkan kinerja (Jogiyanto, 2007).

c. Sikap terhadap perilaku $\left(\mathrm{X}_{3}\right)$ Sikap terhadap perilaku (attitude) didefinisikan sebagai perasaan positif dan negatif seseorang jika harus melakukan perilaku yang akan ditentukan (Davis, et.al, 1989)

d. Minat pengguna terhadap perilaku $\left(\mathrm{X}_{4}\right)$

Minat pengguna terhadap perilaku (behavioral) didefinisikan sebagai kecenderungan untuk tetap menggunaka teknologi (Davis, et.al, 1989)

e. Penggunaan Nyata $\left(X_{5}\right)$

Pengguna nyata (actual use) yaitu keadaan yang nyata dalam penggunaan teknologi yang dalam bentuk pengukurannya dapat dilihat dari frekuensi dan durasi waktu 
dalam menggunakan teknologi tersebut (Davis, et.al, 1989).

Tabel 3.1. Variabel dan konsep kisi kisi penelitian

\begin{tabular}{|c|c|c|c|}
\hline Variabel & Dimensi & Indikator & $\begin{array}{c}\text { Refere } \\
\text { nsi }\end{array}$ \\
\hline \multirow{4}{*}{$\begin{array}{c}\text { Perceived } \\
\text { Ease of } \\
\text { Use }\end{array}$} & $\begin{array}{l}\text { Kemudaha } \\
\text { n untuk } \\
\text { diakses }\end{array}$ & $\begin{array}{l}\text { Saat menggunakan sistem } \\
\text { informasi tidak terbatas } \\
\text { aksesnya pada waktu dan } \\
\text { tempat }\end{array}$ & \multirow{4}{*}{$\begin{array}{l}\text { Davis } \\
\text { (1989) }\end{array}$} \\
\hline & $\begin{array}{l}\text { Fleksibilita } \\
\text { s }\end{array}$ & $\begin{array}{l}\text { Kemudahan dalam } \\
\text { mengadaptasikan sistem } \\
\text { informasi dengan } \\
\text { perangkat komputer }\end{array}$ & \\
\hline & $\begin{array}{l}\text { Kemudaha } \\
\text { n untuk } \\
\text { dipahami }\end{array}$ & $\begin{array}{l}\text { Saat menggunakan sistem } \\
\text { informasi Akademik, } \\
\text { sangat mudah dipahami }\end{array}$ & \\
\hline & $\begin{array}{l}\text { Kemudaha } \\
\text { n untuk } \\
\text { digunakan }\end{array}$ & $\begin{array}{l}\text { Kemudahan dalam } \\
\text { menggunakan sistem } \\
\text { informasi Akademik. }\end{array}$ & \\
\hline \multirow{4}{*}{$\begin{array}{c}\text { Perceived } \\
\text { Usefulnes } \\
\quad s\end{array}$} & $\begin{array}{l}\text { Pemenuha } \\
\mathrm{n} \\
\text { kebutuhan } \\
\text { informasi }\end{array}$ & $\begin{array}{l}\text { Sistem informasi } \\
\text { Akademik digunakan } \\
\text { untuk memenuhi } \\
\text { kebutuhan informasi } \\
\text { (satuan pendidikan, } \\
\text { ketenagaan, peserta didik) }\end{array}$ & \multirow{4}{*}{$\begin{array}{l}\text { Davis } \\
(1989) \\
\text {; Chin } \\
(1991)\end{array}$} \\
\hline & Efektif & $\begin{array}{l}\text { Penggunaan SIAKAD } \\
\text { akan mempercepat proses } \\
\text { layanan }\end{array}$ & \\
\hline & $\begin{array}{l}\text { Meningkat } \\
\text { kan kinerja }\end{array}$ & $\begin{array}{l}\text { Penggunaan SIAKAD } \\
\text { akan memberikan } \\
\text { informasi akurat }\end{array}$ & \\
\hline & $\begin{array}{l}\text { Meningkat } \\
\text { kan } \\
\text { Efisiensi }\end{array}$ & $\begin{array}{l}\text { Penggunaan SIAKAD } \\
\text { akan lebih menghemat }\end{array}$ & \\
\hline \multirow{4}{*}{$\begin{array}{c}\text { Attitude } \\
\text { Toward } \\
\text { Using }\end{array}$} & $\begin{array}{l}\text { Kenyaman } \\
\text { an }\end{array}$ & $\begin{array}{l}\text { Saat berinteraksi dengan } \\
\text { sistem informasi tidak } \\
\text { merasa terbebani }\end{array}$ & \multirow{4}{*}{$\begin{array}{l}\text { Davis } \\
\text { (1989) }\end{array}$} \\
\hline & $\begin{array}{l}\text { Senang } \\
\text { mengguna } \\
\text { kan }\end{array}$ & $\begin{array}{l}\text { Saat menggunakan sistem } \\
\text { informasi merasa aman }\end{array}$ & \\
\hline & Kepuasan & $\begin{array}{l}\text { Merasa puas terhadap } \\
\text { kinerja sistem informasi }\end{array}$ & \\
\hline & $\begin{array}{l}\text { Menumbu } \\
\text { hkan } \\
\text { motivasi }\end{array}$ & $\begin{array}{l}\text { Menumbuhkan motivasi } \\
\text { untuk menggunakan }\end{array}$ & \\
\hline $\begin{array}{c}\text { Behaviora } \\
\text { lintention } \\
\text { to Use }\end{array}$ & $\begin{array}{l}\text { Berupaya } \\
\text { memberika } \\
\mathrm{n} \\
\text { informasi }\end{array}$ & $\begin{array}{l}\text { Mempunyai niat } \\
\text { memberikan data yang } \\
\text { akurat }\end{array}$ & $\begin{array}{l}\text { Davis } \\
\text { (1989) }\end{array}$ \\
\hline
\end{tabular}

\begin{tabular}{|c|c|c|c|}
\hline Variabel & Dimensi & Indikator & $\begin{array}{c}\text { Refere } \\
\text { nsi }\end{array}$ \\
\hline & $\begin{array}{l}\text { Berupaya } \\
\text { mengguna } \\
\text { kan }\end{array}$ & $\begin{array}{l}\text { Mempunyai niat untuk } \\
\text { menggunakan layanan } \\
\text { yang ada }\end{array}$ & \\
\hline & $\begin{array}{l}\text { Berupaya } \\
\text { menjaga } \\
\text { informasi }\end{array}$ & $\begin{array}{l}\text { Mempunyai niat untuk } \\
\text { menjaga sistem informasi } \\
\text { AKADEMIK dan output } \\
\text { informasi }\end{array}$ & Davis \\
\hline & $\begin{array}{l}\text { Pemanfaat } \\
\text { an } \\
\text { Teknologi }\end{array}$ & $\begin{array}{l}\text { Mempunyai niat untuk } \\
\text { tetap menggunakan } \\
\text { teknologi }\end{array}$ & (1989) \\
\hline \multirow{4}{*}{$\begin{array}{l}\text { Actual } \\
\text { System } \\
\text { Usage }\end{array}$} & $\begin{array}{l}\text { Frekuensi } \\
\text { penggunaa } \\
\mathrm{n}\end{array}$ & $\begin{array}{l}\text { Seringnya menggunakan } \\
\text { sistem informasi } \\
\text { pendataan AKADEMIK }\end{array}$ & \multirow{4}{*}{$\begin{array}{l}\text { Davis } \\
\text { (1989) }\end{array}$} \\
\hline & $\begin{array}{l}\text { Kepuasan } \\
\text { pengguna }\end{array}$ & $\begin{array}{l}\text { Kepuasan dalam } \\
\text { penggunaan sistem } \\
\text { informasi AKADEMIK }\end{array}$ & \\
\hline & $\begin{array}{l}\text { Prestice } \\
\text { pengguna }\end{array}$ & $\begin{array}{l}\text { Ada rasa bangga saat } \\
\text { menggunakan sistem } \\
\text { informasi AKADEMIK }\end{array}$ & \\
\hline & Informatif & $\begin{array}{l}\text { Menyampaikan rasa puas } \\
\text { menggunakan sistem } \\
\text { informasi kepada } \\
\text { pengguna lain }\end{array}$ & \\
\hline
\end{tabular}

\subsection{Implementasi}

\subsubsection{Populasi}

Menurut Sugiono (2005 : 90), populasi adalah wilayah generalisasi yang terdiri atas objek/subjek yang mempunyai kualitas dan karakteristik tertentu yang ditetapkan oleh peneliti untuk dipelajari dan kemudian ditarik kesimpulannya. Berdasarkan pengertian tersebut, maka yang menjadi populasi dalam penelitian ini adalah tenaga operator SIAKAD dan Mahasiswa se Universitas Sang Bumi Ruwa Jurai. 


\subsubsection{Sampel}

Sampel adalah sebagian dari populasi yang digunakan sebagai sumber data. Dalam penelitian ini teknik penentuan sampel yang digunakan adalah sampling jenuh. Sampling jenuh adalah teknik penentuan sampel bila semua anggota populasi digunakan sebagai sampel, atau penelitian yang ingin membuat generalisasi dengan kesalahan yang sangat kecil. Istilah lain sampel jenuh adalah sensus, dimana anggota populasi dijadikan sampel (Sugiyono, 2005).

Tabel 3.2 Daftar Jumlah Responden Siakad

\begin{tabular}{||c|l|c||}
\hline \hline NO. & \multicolumn{1}{|c||}{ FAKULTAS } & $\begin{array}{c}\text { Jumlah } \\
\text { Mahasiswa }\end{array}$ \\
\hline 1 & EKONOMI & 25 \\
\hline 2 & TEKNIK & 25 \\
\hline 3 & HUKUM & 25 \\
\hline 4 & FISIPOL & 25 \\
\hline 5 & Operator & 104 \\
\hline \hline \multicolumn{2}{|c|}{ TOTAL }
\end{tabular}

Sumber : Universitas Saburai

\subsubsection{Teknik Pengumpulan Data}

Untuk memperoleh data dan informasi yang lengkap mengenai hal-hal yang akan dikaji dalam penelitian ini yaitu menggunakan kuesioner. Kuisioner ini berisikan daftar pernyataan yang disusun oleh penulis untuk mengetahui bagaimana pengaruh antar konstruk, yaitu
; (1) persepsi pengguna terhadap kemudahan menggunakan sistem informasi Akademik (perceived ease of use), (2) persepsi pengguna terhadap manfaat sistem informasi Akademik (perceived usefulness), (3) sikap pengguna terhadap pemanfaatan sistem informasi Akademik (attitude toward using), (4) Minat pengguna (Behavioral Intention to Use), dan (5) pengguna nyata sistem informasi Akademik (actual system use) dari responden terhadap pemanfaatan sistem informasi Akademik.

Teknik pengumpulan data akan dilakukan secara langsung dari objek penelitian melalui beberapa teknik pengumpulan data yaitu :

a. Studi Dokumentasi

Mengumpulkan data berupa data jumlah Mahasiswa di masing-masing Fakultas melalui petugas operator.

b. Observasi

Mengamati secara langsung pemanfaatan sistem informasi Akademik.

c. Penyebaran Kuesioner

Memberikan kuesioner ke 100 responden yang dalam hal ini adalah petugas operator Siakad dan operator siakad mengambil 25 mahasiswa di setiap Fakultas . 


\subsubsection{Pengukuran Variabel}

Untuk mempermudah penguasaan Variabel dan pengukuran maka dibuat tabel penjelasan atas variabel dan pengukuran tersebut sebagai berikut :

a. Tabel 3.3. Varibel persepsi kemudahan penggunaan (Perceived Ease of Use/ PeoU)

\begin{tabular}{|l|l|c|c|c|c|c|}
\hline NO & \multicolumn{1}{|c|}{ Variabel Konstruk } & STS & TS & KS & S & SS \\
\hline 1 & $\begin{array}{l}\text { Sistem Informasi } \\
\text { Akademik mudah diakses }\end{array}$ & 1 & 2 & 3 & 4 & 5 \\
\hline 3 & $\begin{array}{l}\text { AKADEMIK mudah } \\
\text { diadaptasikan dengan } \\
\text { perangkat komputer yang } \\
\text { ada disekolah }\end{array}$ & 1 & 2 & 3 & 4 & 5 \\
\hline 4 & $\begin{array}{l}\text { AKADEMIK, mudah } \\
\text { untuk dipelajari dan } \\
\text { dipahami }\end{array}$ & 1 & 2 & 3 & 4 & 5 \\
\hline $\begin{array}{l}\text { Fasilitas/fitur yang ada } \\
\text { AKADEMIK, mudah } \\
\text { untuk digunakan }\end{array}$ & 1 & 2 & 3 & 4 & 5 \\
\hline
\end{tabular}

Item - item pertanyaan diadaptasi dari

Davis et.al, 1989 dan chau

b. Tabel 3.4. Variabel persepsi kemanfaatan (Perceived Usefullness/PU)

\begin{tabular}{|c|l|c|c|c|c|c|}
\hline NO & Variabel Konstruk & STS & TS & KS & S & SS \\
\hline 1 & $\begin{array}{l}\text { Penggunaan Sistem } \\
\text { Informasi AKADEMIK } \\
\text { sudah sesuai untuk } \\
\text { memenuhi kebutuhan } \\
\text { pendataan di Universitas } \\
\text { (satuan pendidikan, } \\
\text { ketenagaan dan peserta } \\
\text { didik) }\end{array}$ & 1 & 2 & 3 & 4 & 5 \\
\hline
\end{tabular}

\begin{tabular}{|c|l|c|c|c|c|c|}
\hline NO & Variabel Konstruk & STS & TS & KS & S & SS \\
\hline 2 & $\begin{array}{l}\text { Penggunaan Sistem } \\
\text { Informasi AKADEMIK } \\
\text { mempercepat dalam } \\
\text { memberikan dan } \\
\text { mendapatkan informasi } \\
\text { sekolah }\end{array}$ & 1 & 2 & 3 & 4 & 5 \\
\hline 3 & $\begin{array}{l}\text { Penggunaan Sistem } \\
\text { Informasi AKADEMIK } \\
\text { dapat menghasilkan } \\
\text { informasi yang akurat } \\
\text { (profil sekolah, kondisi } \\
\text { ketenagaan dan kondisi } \\
\text { peserta didik) }\end{array}$ & 1 & 2 & 3 & 4 & 5 \\
\hline 4 & $\begin{array}{l}\text { Penggunaan Sistem } \\
\text { Informasi AKADEMIK } \\
\text { lebih menghemat biaya }\end{array}$ & 1 & 2 & 3 & 4 & 5 \\
\hline
\end{tabular}

Item - item pertanyaan diadaptasi dari

Davis et.al, 1989 dan chau

c. Tabel 3.5. Variabel Sikap terhadap perilaku (Attitude Toward Using / ATU)

\begin{tabular}{|c|c|c|c|c|c|c|}
\hline NO & Variabel Konstruk & STS & TS & KS & $S$ & SS \\
\hline 1 & $\begin{array}{l}\text { Saya merasa nyaman dalam } \\
\text { berinteraksi dengan Sistem } \\
\text { Informasi AKADEMIK }\end{array}$ & 1 & 2 & 3 & 4 & 5 \\
\hline 2 & $\begin{array}{l}\text { Saya senang menggunakan } \\
\text { sistem informasi } \\
\text { AKADEMIK }\end{array}$ & 1 & 2 & 3 & 4 & 5 \\
\hline 3 & $\begin{array}{l}\text { Saya merasa puas dengan } \\
\text { sistem informasi } \\
\text { AKADEMIK untuk } \\
\text { pendataan terpadu }\end{array}$ & 1 & 2 & 3 & 4 & 5 \\
\hline 4 & $\begin{array}{l}\text { Menu tampilan dan content } \\
\text { menumbuhkan motivasi } \\
\text { menggunakan }\end{array}$ & 1 & 2 & 3 & 4 & 5 \\
\hline
\end{tabular}

Item - item pertanyaan diadaptasi dari Karashanna,2000 
d. Tabel 3.6. Variabel Kecenderungan perilaku untuk tetap menggunakan suatu teknologi (Behavioral Intention to Use / BITU)

\begin{tabular}{|c|c|c|c|c|c|c|}
\hline NO & Variabel Konstruk & STS & TS & KS & $\mathrm{S}$ & SS \\
\hline 1 & $\begin{array}{l}\text { Saya menggunakan sistem } \\
\text { informasi AKADEMIK } \\
\text { untuk memberikan } \\
\text { informasi yang akurat } \\
\text { (profil sekolah, kondisi } \\
\text { ketenagaan dan kondisi } \\
\text { peserta didik) }\end{array}$ & 1 & 2 & 3 & 4 & 5 \\
\hline 2 & $\begin{array}{l}\text { Saya akan selalu } \\
\text { menggunakan sistem } \\
\text { informasi AKADEMIK } \\
\text { karena kontennya lengkap }\end{array}$ & 1 & 2 & 3 & 4 & 5 \\
\hline 3 & $\begin{array}{l}\text { Saya akan selalu menjaga } \\
\text { sistem informasi } \\
\text { AKADEMIK dan informasi } \\
\text { yang dihasilkannya }\end{array}$ & 1 & 2 & 3 & 4 & 5 \\
\hline 4 & $\begin{array}{l}\text { Saya akan tetap } \\
\text { menggunakan sistem } \\
\text { informasi AKADEMIK } \\
\text { untuk pemenuhan data dan } \\
\text { informasi sekolah }\end{array}$ & 1 & 2 & 3 & 4 & 5 \\
\hline
\end{tabular}

Item - item pertanyaan diadaptasi dari

Davis et.al, 1989

e. Tabel 3.7. Variabel Kondisi nyata pengguna sistem (Actual System Usage / ASU)

\begin{tabular}{|c|c|c|c|c|c|c|}
\hline NO & Variabel Konstruk & STS & TS & KS & $\mathrm{S}$ & SS \\
\hline 1 & $\begin{array}{l}\text { Saya menggunakan Sistem } \\
\text { Informasi AKADEMIK } \\
\text { untuk data dan informasi } \\
\text { sekolah setiap hari }\end{array}$ & 1 & 2 & 3 & 4 & 5 \\
\hline 2 & $\begin{array}{l}\text { Secara keseluruhan saya } \\
\text { merasa puas dengan kinerja } \\
\text { Sistem Informasi Layanan } \\
\text { AKADEMIK }\end{array}$ & 1 & 2 & 3 & 4 & 5 \\
\hline 3 & $\begin{array}{l}\text { Saya merasa bangga } \\
\text { menggunakan sistem } \\
\text { informasi AKADEMIK }\end{array}$ & 1 & 2 & 3 & 4 & 5 \\
\hline
\end{tabular}

\begin{tabular}{|c|l|c|c|c|c|c|}
\hline NO & \multicolumn{1}{|c|}{ Variabel Konstruk } & STS & TS & KS & S & SS \\
\hline 4 & $\begin{array}{l}\text { Saya menyampaikan } \\
\text { kepuasan terhadap Sistem } \\
\text { Informasi AKADEMIK } \\
\text { kepada petugas operator } \\
\text { lain. }\end{array}$ & 1 & 2 & 3 & 4 & 5 \\
\hline
\end{tabular}

Item - item pertanyaan diadaptasi dari

Davis, 2003

\subsection{Evaluasi}

\subsubsection{Uji Validitas dan Realibilitas}

Uji validitas dan realibilatas dimaksudkan untuk menguji valid dan reliable dari item - item pembentuk konstruk. Uji validitasnya dilakukan dengan cara uji validitas tampang (face falidity). Yaitu dengan membentuk suatu studi pilot (pilot study) yang melibatkan beberapa partisipan untuk mengkonfirmasi item item yang membentuk konstruk konstruk tersebut. Dalam uji ini ukuran sampel dibuat sekitar 10 sampai 30 responden, yaitu responden yang benar-benar memahami tentang isu penelitan yang dilakukan yaitu operator dan mahasiswa. yang berjumlah 25 orang.

Uji validitas dilakukan untuk membuang atau mengganti item item yang kurang cocok dalam membentuk konstruk konstruk yang diinginkan sehingga item-item pertanyaan awal dapat dimengerti oleh calon partisipan atau responden servei. Setelah item-item dalam membentuk konstruk konstruk 
ditentukan, maka tahap selanjutnya item item tersebut diuji reliabilitasnya. Hal ini dimaksudkan untuk memastikan item item apa saja yang valid membentuk konstruk konstruk tersebut dengan cara dihitung berdasarkan nilai Cronbach's Alpha menggunakan Aplikasi IBM SPSS Statistic 20. Jika variabel mendekati nilai atau lebih besar sama dengan 0,7 maka data dapat dikatakan reliable (Sugiyono, 2007).

Tabel 3.8 Kriteria Tingkat Reliabilitas

\begin{tabular}{|c|c|c|}
\hline No & Interval & Kriteria \\
\hline 1 & $<0,200$ & Sangat Rendah \\
\hline 2 & $0,200-0,399$ & Rendah \\
\hline 3 & $0,400-0,599$ & Cukup \\
\hline 4 & $0,600-0,799$ & Tinggi \\
\hline 5 & $0,800-1,000$ & Sangat Tinggi \\
\hline
\end{tabular}

\subsubsection{Uji Hipotesis}

Hipotesis yang diajukan dalam penelitian ini adalah :

Hipotesis 1: Persepsi Kemudahan

(Perceived Ease of Use)

berpengaruh positif terhadap

persepsi kegunaan

(Perceived Usefullness).

Hipotesis 2 : Persepsi Kegunaan

(Perceived Usefullness)

berpengaruh positif terhadap

sikap pengguna (Attitude

Toward Using).

Hipotesis 3 :Peserpsi Kemudahan

(Perceived Ease of Use) berpengaruh positif terhadap

sikap pengguna (Attitude

Toward Using).

Hipotesis 4 : Sikap pengguna (Attitude

Toward Using) berpengaruh positif terhadap minat pengguna teknologi

(Behavioral Intention to Use).

Hipotesis 5: Minat penggunaan

(Behavioral Intention to Use) berpengaruh positif terhadap pengguna nyata (Actual System Usage)

Pengujian hipotesis dilakukan dengan SEM (Structural Eqution Modeling) menggunakan software LISREL (LInear Structural RELationship) Versi 8.72. SEM (Structural Equation Modelling). Apabila nilai $C R> \pm 2,0$ maka hipotesis diterima.

\section{BAB IV}

\section{HASIL PENELITIAN DAN PEMBAHASAN}

\subsection{Deskripsi Data}

Penelitian ini menggunakan 5 variabel laten (konstruk) yang dituangkan dalam 20 item (indikator) pertanyaan, yang dibangun berdasarkan teori yang sudah digunakan oleh beberapa peneliti terdahulu yaitu Technology Acceptance Model (TAM). 
Penentuan dan peletakan setiap item-item pertanyaan dalam setiap konstruk pada Technology Acceptance Model (TAM) dilakukan dengan cara uji validitas tampang (face falidity), yaitu dengan membentuk suatu studi pilot (pilot study) yang melibatkan 4 orang operator Siakad dan 21 Mahasiswa di masing -masing fakultas. Setelah didapatkan hasil uji pre kuisioner, kemudian dianalisis menggunakan Aplikasi IBM SPSS Statistic. Hasilnya menunjukan bahwa nilai Cronbach's Alpha reliabilitas kuisioner terbukti valid dengan mencapai angka 0,710 atau melebihi nilai yang minimal disyaratkan yaitu 0,700 .

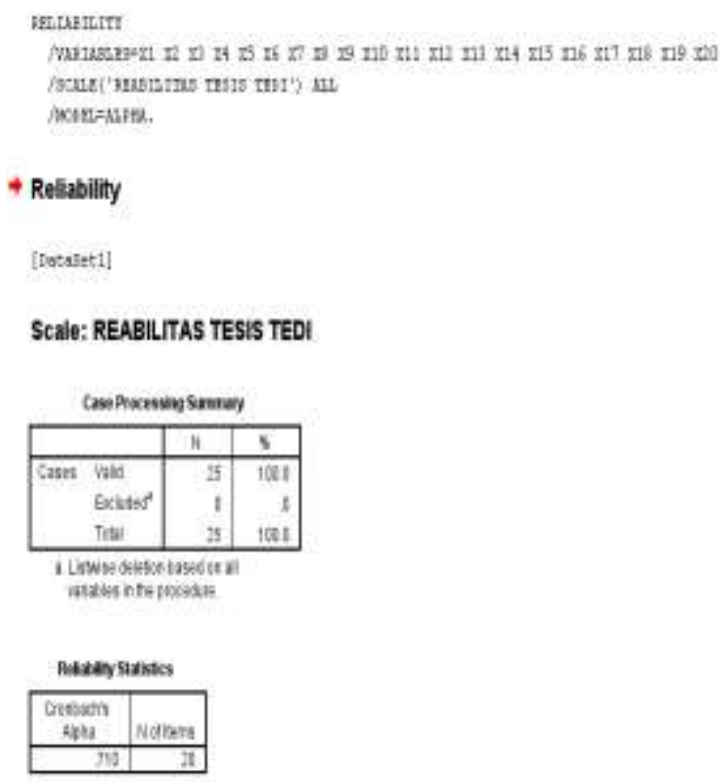

Gambar 4.1 : Hasil analisis realibilitas data

\subsection{Analisis data berdasarkan asumsi CB-SEM}

Sebelum menggunakan Structural Equation Modeling (SEM) khususnya Covariance Based Structural Equation Modeling (CB-SEM) dengan metoda Maximum Likelihood (ML), perlu terlebih dahulu memenuhi asumsi asumsi antara lain ;

a. Jumlah Sampel

Jumlah sampel yang digunakan dalam penelitian ini adalah 104, sehingga sudah memenuhi prasyarat yang ditentukan yaitu $100-150$ sampel.

b. Outlier dan Normalitas Data

Data yang dihasilkan dari 104 sampel yang digunakan, perlu dilakukan screening data untuk mengetahui multivariate normalitas data. Pengujian dilakukan melalui uji perform tests of multivariate normality dengan menggunakan LISREL 8.72. Berikut hasilnya ;

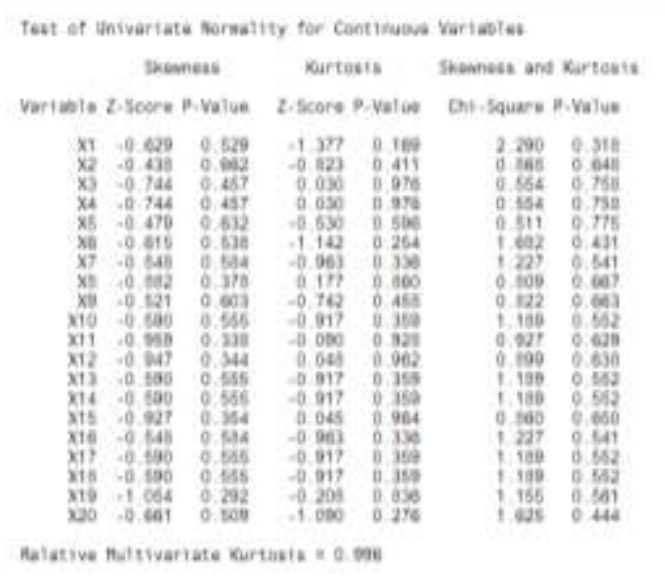

Gambar 4.2: Hasil uji normalitas data 
Dari hasil estimasi menggunakan normal score di atas dapat dilihat bahwa data kita sudah normal baik secara univariate maupun multivariate dengan $\mathrm{P}$ value untuk skewwness dan kurtosis $>0,05$. Sehingga data maupun model dapat dilanjutkan ke tahap berikutnya untuk untuk menghasilkan solusi estimasi model dan goodness of fit.

\section{c. Multikolinearitas}

Berdasarkan data sejumlah 104 sampel yang digunakan, untuk mengetahui data ada tidaknya multikolinearitas, maka data diuji kolerasi matriks dengan menggunakan Aplikasi LISREL 8.72 untuk memastikan bahwa nantinya model yang dihasilkan akan dapat memberikan solusi estimasi model. Berikut hasil pengujiannya ;

\begin{tabular}{|c|c|c|c|c|c|}
\hline & $\mathrm{XI}$ & 12 & 16 & II & $\mathrm{k}$ \\
\hline$x$ & $1 \mathrm{mog}$ & & & & \\
\hline$x$ & 1.186 & $10 \mathrm{~N}$ & & & \\
\hline $\mathrm{B}$ & D.13 & 0.25 & 1.000 & & \\
\hline g & 0.174 & 12. & 0.138 & 1.100 & \\
\hline 16 & 1.760 & 0.21 & -1) 64 & 8.78 & 1. 10 \\
\hline 16 & 6766 & $0.3 \%$ & 0.14 & 0.10 & 0.283 \\
\hline X? & -1 ing & 0.2 .2 & 1.62 & 1.186 & -8.09 \\
\hline$x$ & 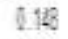 & 0.118 & 128 & 1.168 & 1034 \\
\hline$x$ & 1780 & 1. .211 & AfR & 826 & 0.16: \\
\hline xi & 1.180 & 1.92 & 105 & 1.480 & Q.111 \\
\hline $\mathrm{xt}$ & 4.64 & -1.94 & 1.19 & 0.1.16 & 0.12 \\
\hline XI & 102 & 1. BAt & 1.115 & 1.197 & 7.t11 \\
\hline $\mathrm{KH}$ & 1.180 & 0.28 & 0.183 & 8.74 & 0.167 \\
\hline$x i$ & 6. IB: & 0.2 & 118 & 1.16? & 3.157 \\
\hline $\mathrm{x} 5$ & 1.138 & 0.218 & 128 & 0.38 & $-1.13 i$ \\
\hline$x: 2$ & IIt & -1.113 & $-1 \mathrm{cos}$ & -1.55 & -1.18 \\
\hline$x 7$ & Btist & 1.28 & 1230 & 0.120 & Q.0.1 \\
\hline$x:$ & 412 & -1070 & 1.66 & -1.79 & -1.07 \\
\hline$x: 8$ & 1. 183 & $0.8 \mathrm{~B}$ & 1.24 & 0.101 & 0.831 \\
\hline X8 & $107 \pi$ & 1.2 .4 & 1.187 & 1. 180 & -8.011 \\
\hline
\end{tabular}

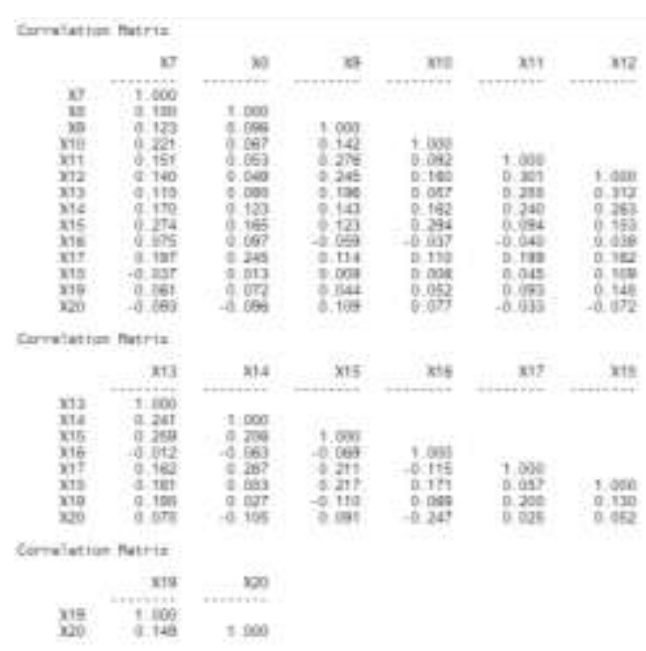

Gambar 4.3 : Hasil uji korelasi data

Hasil pengujian multikolinearitas dengan uji korelasi diatas, diketahui bahwa data yang diperoleh tidak ada angka yang melebihi $\quad 0,90$ pada korelasi antar variabel independen. Sehingga dapat dikatakan bahwa data secara keseluruhan telah layak dan memenuhi asumsi-asumsi untuk dilakukan pengukuran dengan Covariance Based Structural Equation Modeling (CBSEM) dengan metoda Maximum Likelihood (ML).

\subsection{Analisis Data Penelitian}

\subsubsection{Spesifikasi Model}

Tahap spesifikasi model pada penelitian ini merupakan langkah awal dalam analisis SEM. Model valid yang akan diukur, yaitu Techonolgy Acceptance Model (TAM) yang ditemukan dan dikembangkan oleh Davis et al (1989). Sehingga di tahap ini peneliti tidak perlu lagi melakukan 
pengukuran dan pegembangan konstruk ataupun item untuk mendapatkan model yang spesifik untuk dianalisa dengan CBSEM karena hal tersebut sudah tersedia pada model Techonolgy Acceptance Model (TAM).

\subsubsection{Identifikasi Model dan Estimasi Model}

Indetifikasi model merupakan titik awal suatu penelitian dapat dilanjutkan atau tidak ke tahap berikutnya. Selain itu juga untuk mengetahui apakah model yang di bangun dengan data empiris tersebut memiliki nilai yang unik ataukah tidak, sehingga model tersebut dapat diestimasi. Jika model tidak memiliki nilai yang unik, maka model tersebut tidak dapat diidentifikasi (unidentified), hal itu disebabkan karena informasi yang terdapat pada data empiris tidak cukup untuk menghasilkan solusi yang unik dalam menghitung parameter estimasi model. Namun karena pada penelitian ini menggunakan alat analisis Covariance Based Structural Equation Modeling (CB-SEM) dengan metode estimasi Maximum Likelihood (ML), maka terjadinya unidentified model semestinya tidak mungkin terjadi. Hal ini disebabkan karena pada metode estimasi Maximum Likelihood merupakan instrumen CBSEM yang sifatnya confirmatory model atau pengujian suatu model dan bukan exploratory model atau pengembangan model. Untuk pembuktiannya, berikut hasil identifikasi model dengan menggunakan LISREL 8.72, berdasarkan Techonology Acceptance Model (TAM) yang digunakan dalam penelitian ini ;

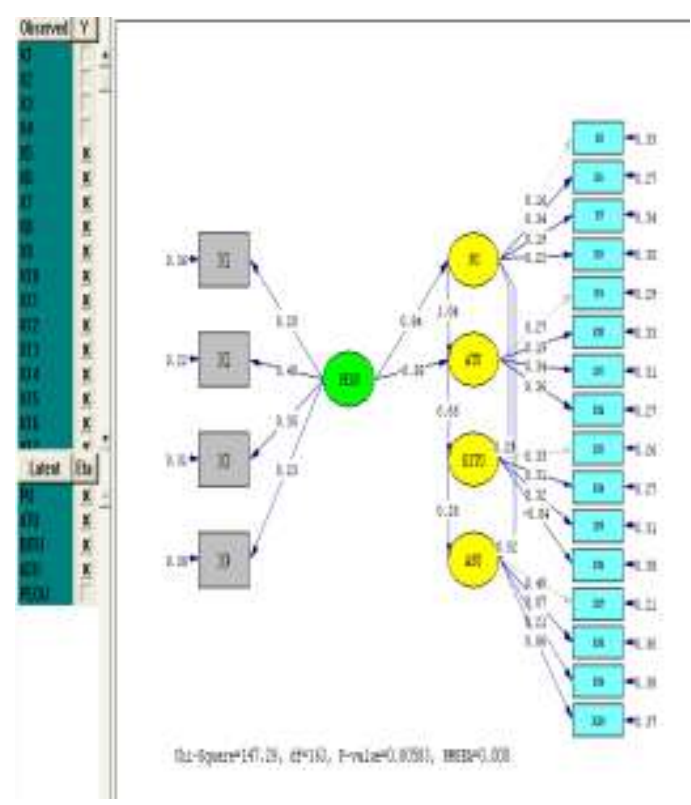

Gambar 4.4.Hasil estimasi Basic Model dari TAM

Hasil pengujian di atas menunjukan bahwa model dapat diidentifikasi, hal ini terlihat pada gambar path diagram dan korelasi yang telah membentuk Technology Acceptance Model (TAM) sebagaimana spesifikasi model yang digunakan. Pengujian mendapatkan hasil nilai untuk P-Value $=0,80583$ dan RMSEA $=0,000$, yang berarti bahwa model fit, sehingga estimasi model telah dapat menghasilkan solusi karena telah memenuhi syarat minimal nilai P-Value $\geq$ 
0,05 dan nilai RMSEA $\leq 0,08$. Sehingga dapat dikatakan bahwa model telah valid.

\subsubsection{Evaluasi Model}

Evaluasi model bertujuan untuk mengevaluasi model secara keseluruhan, apakah model mempunyai fit yang baik atau tidak. Hasil perhitungan yang terlihat pada path diagram dan korelasi yang terbentuk sesuai Technology Acceptance Model (TAM) sebagaimana spesifikasi model yang digunakan. Selain itu juga model dari hasil uji goodness of fit berdasarkan cut of value tentang asumsi asumsi dasar pengujian Structural Equation Modeling (SEM) telah memenuhi syarat, sebagaimana terlihat pada gambar berikut ;

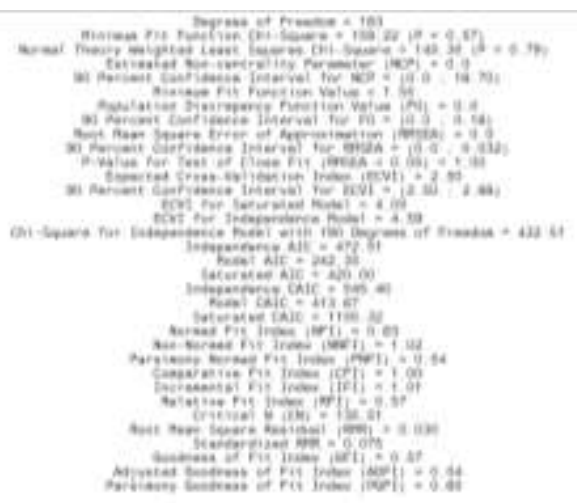

Gambar 4.5.Hasil evaluasi penelitian dengan model dari TAM

a. Nilai Chi-Square hasil perhitungan pada $\mathrm{df}=163$ adalah 159,22 $\quad(\mathrm{p}=$ 0,57). Sedangkan karakteristik goodness of fit yang ideal memiliki Chi-Square yang diharapkan kecil.
Jika di lihat dari nilai $\mathrm{P}$ yang cukup kecil dengan $\mathrm{p}=0.57$, maka model dapat dikatakan fit.

b. Nilai Goodness of Fit Index (GFI) adalah ukuran indeks kesesuaian model $\geq 0,90$ adalah good fit, sedangkan dengan angka kisaran 0,80 $\leq \mathrm{GFI} \leq 0,90$ adalah marjinal fit. Berdasarkan data yang diperoleh, maka model termasuk kategori marjinal fit atau cukup fit dengan nilai GFI $=0,87$ atau lebih besar dari 0,80 dan lebih kecil dari 0,90 sebagaimana yang disyaratkan, sehingga model dikategorikan cukup fit untuk dapat memberikan solusi.

c. Nilai Ajusted Goodness of Fit Index (AGFI) juga merupakan gambaran kesesuaian model dikategorikan good fit yang mensyaratkan nilai $\geq 0,90$. Sedangkan kisaran nilai $0,80 \leq$ AGFI $\leq 0,90$ merupakan marjinal fit. Dari hasil analisis perhitungan yang diperoleh diatas, maka model dapat dikatakan majinal fit atau cukup fit dengan nilai $=0,84$ sehingga sudah cukup untuk memberikan solusi.

d. Nilai TLI (Tucker Lewis Index) atau Non Normed Fit Index (NNFI) adalah sebuah alternatif incremental fit index yang membandingkan sebuah model yang diuji terhadap sebuah base line model. Nilai yang diharapkan adalah 
TLI $\geq 0,90$. Hasil perhitungan TLI atau NNFI pada penelitian ini menunjukan nilai 1.02, maka model dikatakan fit.

e. Nilai Comparatif Fit Index (CFI) adalah merupakan angka perbandingan model empiris dengan model nullnya., nilai CFI yang diharapkan adalah $\geq 0.95$. Hasil perhitungan yang tertera pada Path diagram adalah 1.00, maka model dapat dikatakan fit untuk memberikan solusi.

f. Nilai Root Mean Square Erorr of Approximation (RMSEA) merupakan kriteria fit indices yang mengukur penyimpangan nilai paramater suatu model dengan matrix kovarians populasinya. Nilai RMSEA yang kurang dari 0.05 mengindikasikan goodness of fit model sangat baik, nilai RMSEA antara $0.05-0.08$ mengindikasikan goodness of fit model cukup baik, sedangkan nilai RMSEA di atas 1.00 mengindikasikan model perlu diperbaiki. Hasil perhitungan pada Path diagram memberikan nilai $\mathrm{RMSEA}=0.000$, maka model dikatakan sangat baik.

Berikut adalah tabel perbandingan Goodness of Fit penelitian dengan Cut of Value dari Goodness of Fit Index yang disyaratkan ;
Tabel 4.1: Ringkasan Goodness of Fit

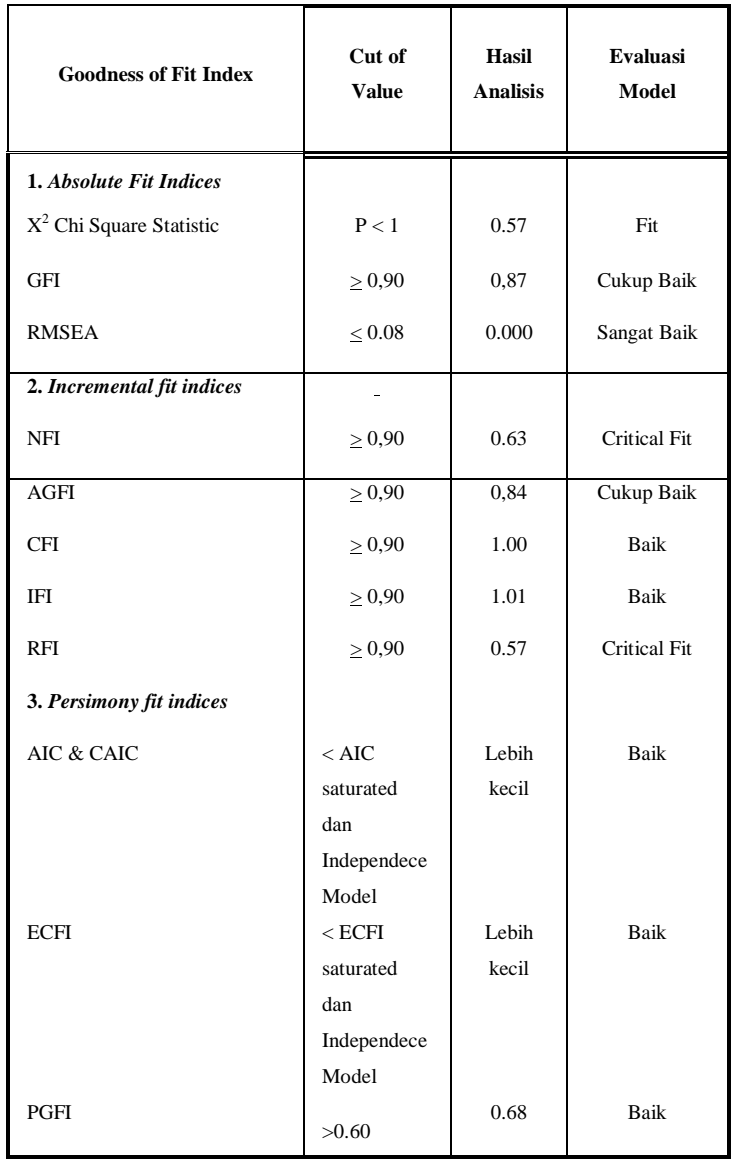

Dari semua kriteria goodness of fit yang disyaratkan di atas, ternyata model Technology Acceptance Model (TAM) setelah dianalisis dengan Covarian Based Structural Equation Modeling (CB-SEM) dengan menggunakan Aplikasi LISREL 8.72 dalam penelitian ini adalah merupakan model yang fit dan sudah dapat memberikan solusi. Hal ini sesuai dengan teori yang dikemukakan Hair et al. (2010) bahwa untuk menilai kelayakan minimal $4-5$ kriteria goodness of fit dari ketiga kriteria yaitu : Absolute Fit Indices, Incremental fit indices, Persimony fit indices dapat terwakili. 


\subsection{Pengujian Hipotesis}

Dari hasil penelitian yang diperoleh setelah basic model ditransfer kedalam estimasi T-values, maka hipotesis penelitian dapat diketahui dengan cara membaca nilai dari Critical Ratio (CR) dari Koefisien Path Diagram pada model yang digunakan. Selain itu sebagaimana hipotesis diawal disampaikan bahwa jika Critical Ratio (C.R) dan Koefisien Path Diagram bernilai $\mathrm{CR}> \pm 2,0$ maka hipotesis diterima. Di bawah ini adalah nilai yang ditunjukkan oleh nilai critical ratio dan koefisien path diagram dibawah ini atas dasar hipotesis awal penelitian ini;

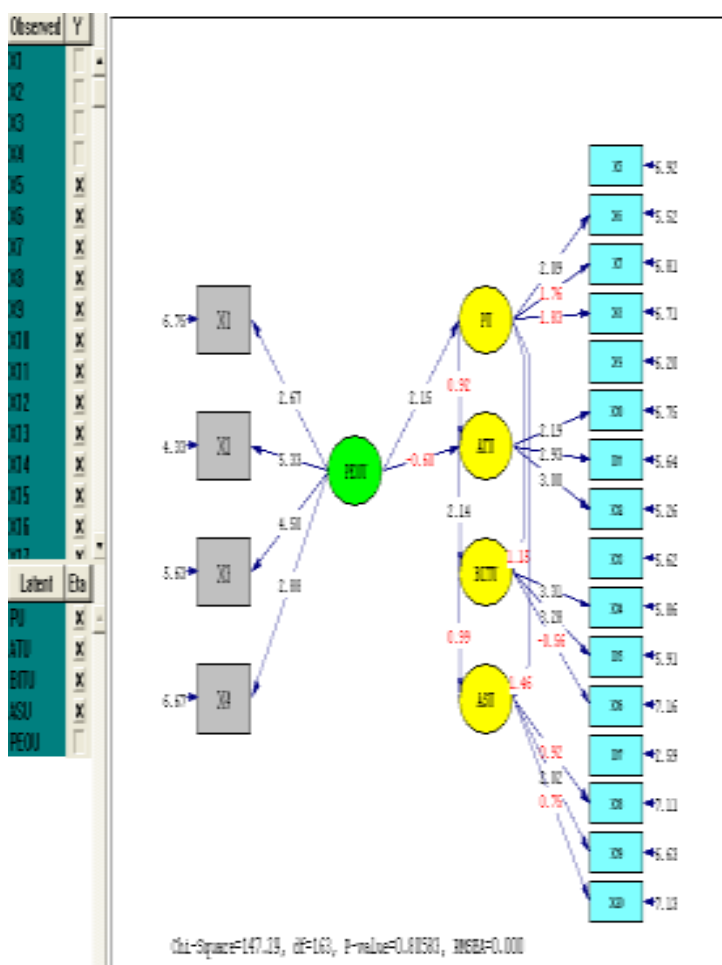

Gambar 4.6. Snapshot Basic Model yang diestimasi ke T-Value
Hasil pengujian hipotesisnya adalah sebagai berukut :

a. Hipotesis pertama diterima, dimana faktor nilai kemudahan (Ease of Use) berpengaruh positif terhadap Kemanfaatan (Usefullness). Hal itu dibuktikan dengan nilai Critical Ratio pada koefisien path diagram $=$ 2,15 atau lebih besar dari nilai yang disyaratkan yaitu $\mathrm{CR}> \pm 2,0$.

b. Hipotesis kedua ditolak, dimana Faktor nilai Kemanfaatan (Usefullness) tidak berpengaruh positif terhadap sikap pengguna (Attitude Toward Using). Hal ini berdasarkan nilai Critical Ratio dan koefisien path diagram yang menunjukkan nilai $=0,92$ sehingga tidak memenuhi standar CR yang disyaratkan yaitu $> \pm 2,0$.

c. Hipotesis ketiga ditolak, dimana Faktor nilai Kemudahan Penggunaan (Ease of Use) tidak berpengaruh positif terhadap pengguna (Attitude Toward Using). Hal itu dibuktikan dengan nilai Critical Ratio dan koefisien path diagram yang menunjukkan nilai $=-0.60$, atau lebih kecil dari standar CR yang disyaratkan $> \pm 2,0$.

d. Hipotesis keempat diterima, dimana faktor nilai Sikap pengguna (Attitude Toward Using) berpengaruh positif 
terhadap minat pengguna teknologi

(Behavioral Intention to Use). Hal itu dibuktikan dengan nilai Critical Ratio dan koefisien path diagram yang menunjukkan nilai $=2,14$, atau lebih besar dari standar CR yang disyaratkan yaitu $> \pm 2,0$, maka hipotesis diterima.

e. Hipotesis kelima ditolak, dimana Faktor nilai Minat penggunaan (Behavioral Intention to Use) berpengaruh negatif terhadap pengguna nyata (Actual System Usage) yang ditunjukkan dengan nilai 0.99, atau lebih kecil dari standar CR yang disyaratkan yaitu > $\pm 2,0$.

\subsection{Pembahasan}

Dari hasil perhitungan dan pengujian hipotesis di atas didapatkan hasil bahwa sistem informasi Akademik dapat diterima pengguna berdasarkan persepsi kemudahan (PEOU) hal ini dapat dilihat dari hasil loading factor pada masing - masing item pertanyaan pada PEOU X1 (2,67), X2 $(6,81)$, X3 $(4,61)$ dan X4 $(2,91)$, hal ini menunjukan bahwa sistem informasi Akademik ini dirasakan mudah oleh pengguna, dan dari hasil estimasi T-value menunjukan korelasi positif terhadap persepsi kemanfaatan (PU).
Selain itu ada beberapa hal yang harus diperbaiki pada sistem informasi Akademik ini yaitu :

a. Dari variabel persepsi kemanfaatan (PU) pada item X5 $(0,00)$, X7 $(1,77)$, X8 $(1,85)$, variabel niat untuk tetap menggunakan (BITU) pada item X13 $(0,00)$ dan X16 $(-0,66)$, serta variabel kondisi nyata pengguna sistem (ASU) pada item X17 (0,00), X 18 $(0,91), \quad$ dan X20 $(0,76)$ yang menunjukan bahwa sistem informasi Akademik ini belum dapat memenuhi kebutuhan pendataan sekolah yaitu :

1. Satuan pendidikan

Kondisi saat ini : pada menu satuan pendidikan belum dapat menampilkan kondisi Satuan Acara Perkuliahan .

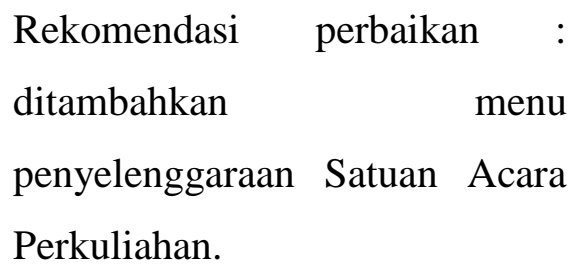

b. Dari variabel sikap terhadap penggunaan sistem (ATU) pada item X9 $(0,00)$, yang menunjukan bahwa ada rasa ketidaknyamanan dalam berinteraksi dengan sistem informasi akademik, yaitu : 
Kondisi saat ini : Sistem informasi akademik belum memiliki tampilan yang baik menurut para pengguna.

Rekomendasi perbaikan : perubahan pada bentuk tampilan yang dapat memenuhi keinginan para pemakai.

\section{BAB V}

\section{KESIMPULAN DAN SARAN}

\subsection{Kesimpulan}

Dari hasil penelitian di atas dapat disimpulkan :

a. Model Technology Acceptance Model (TAM) dapat digunakan pada penelitian ini. Hal ini dibuktikan dengan terpenuhinya ketentuan pada 3 kriteria goodness of fit yaitu : Absolute Fit Indices, Incremental fit indices, Persimony fit indices.

b. Dari hasil pengujian, hipotesis yang ditolak pada penelitian ini adalah faktor kemudahan (Ease of Use) tidak berpengaruh positif sikap pengguna (Attitude Toward Using) (H3), faktor kemanfaatan (Usefullness) tidak berpengaruh positif terhadap sikap pengguna (Attitude Toward Using) (H2) dan minat pengguna teknologi (Behavioral Intention to Use) tidak berpengaruh positif terhadap pengguna nyata (Actual System Usage) (H5).

c. Hipotesis yang diterima pada penelitian ini adalah faktor kemudahan (Ease of Use) berpengaruh positif faktor kemanfaatan (Usefullness) (H1), dan faktor sikap pengguna (Attitude Toward Using) berpengaruh positif terhadap minat pengguna teknologi (Behavioral Intention to Use) (H4).

d. Dari hasil penelitian dan pengujian hipotesis, maka perlu perbaikan pada pengembangan sistem informasi akademik ini yaitu pembuatan sebuah rancangan sistem yang dapat mengakomodir semua kebutuhan pendataan kampus (SAP, ketenagaan dan peserta didik) serta perbaikan pada tampilan yang lebih nyaman dan aman.

\subsection{Saran}

Dari kesimpulan di atas, ada beberapa saran yang di ajukan untuk perbaikan pengembangan sistem informasi akademik ini :

a. Pengembangan sistem informasi akademik perlu memperhatikan faktor kemudahan (Ease of Use) dan kebermanfaatan (Usefullness), 
sehingga sistem informasi yang bersifat mandatory (wajib) seperti ini dapat diterima oleh pengguna atau operator.

b. Dalam penelitian ini, penulis hanya menganalisis sikap pengguna terhadap sistem informasi akademik. Oleh karena itu, untuk penelitian selanjutnya diharapkan agar dapat membuat rancangan sistem sebagai masukan kepada pihak pengelola sistem informasi akademik untuk meningkatkan kepuasan pengguna atau operator.

\section{DAFTAR PUSTAKA}

Adams, D. A., Nelson, R. R., \& Todd, P. A. 1992. Perceived, usefullness, ease of use, and usage of information; A replication. MIS Quarterly, 16(2), 227-247.

Arikunto, Suharsmini. 2009. Prosedur Penelitian: Suatu Pendekatan Praktik. Jakarta. Rhineka Cipta.

Arif Wibowo. 2007. “ Kajian Tentang Perilaku Pengguna Sistem Informasi Dengan Pendekatan Technology Acceptance Model (TAM)" (Skripsi). Jakarta : Program Studi Sistem Informasi Fakultas Teknologi Informasi, Universitas Budi Luhur Jakarta.

Benslimane, Plaisent, dan Bernard. 2004. Using Web Systems For EProcurement; An Extension Of The Unified Theory Of Acceptance And Use Of Technology. Florida.
Bollen, K.A., and Long, J.S. 1993. Testing Structural Equation Models. Newbury Park, CA: Sage.

Chin, W Wynne dan Todd Peter.1991. "On The use Usefullness,ease of use of structural equation Modeling in MIS Research : A note of Caution.

Davis, FD. 1989. Perceived

Usefulness, Perceived Ease of Use, and User Acceptance of Information Technology, MIS Quarterly September 1989.

Direktorat pendidikan menengah. 2012. Panduan PAS SMK, Jakarta. Ditpsmk

Direktorat pendidikan menengah. 2012. Sistem Pendataan Online Menengah, Jakarta. Ditpsmk.

Edi Riadi. 2013. Aplikasi LISREL untuk Penelitian Analisis Jalur. Penerbit Andi, Yogyakarta.

Ferdinand, Augusty. 2002. Structural Equation Modeling Dalam Penelitian Manajemen. Semarang. BP Undip.

Ghozali, I. 2005. Structural Equation Modeling Metode Alterantif Dengan Linear Strutural Relationship. Semarang : BP.Universitas Diponegoro

Hair, Joseph F., William C. Black, Barry J. Babin, and Rolph E. Andersor. 2010. Multivariate Data Analisys, Englewood Cliffs, NJ . Pretice Hall.

Harizanova, Adriana, 2003. Management Information System in Tailoring Industry, Academic Open Internet Journal, volume 9. 
Hendro Purnomo. 2012. Persepsi Operator Sistem Informasi Manajemen Tentang Pelaksanaan Paket Aplikasi Sekolah (PAS) dan Kualitas Informasi Di Wilayah Jabodetabek. (Tesis). Jakarta. Program Pascasarjana Ilmu Administrasi dan Kebijakan Pendidikan.

Hengky, 2013, Structural Equation Modeling Konsep dan Aplikasi. Bandung. Penerbit ALFABETA.

Husen, Muhhamad. 2013. A questionnaire approach based on the Technology acceptance model for mobile Tracking on patient progress applications. Saudi Arabia. Al-Qassim University.

http://pendataan.dikmen.kemdikbud.go.id

Indrajit. 2000. Pengantar Konsep Dasar Manajemen Sistem Infromasi dan Teknologi Informasi. Jakarta. Elex Media Komputindo

Jogiyanto, HM., 2005. Analisis dan Desain Sistem Informasi: Pendekatan Terstruktur Teori dan Praktek Aplikasi Bisnis. Yogyakarta. Andi Offset.

Kripanont, Napaporn. 2007. Examining a Technology Acceptance Model of Internet Usage by Academics within Thai Business Schools. (Thesis). Australia. Victoria University.

Lili Adiwibowo. 2009. Analisis Perilaku Pengguna Teknologi Informasi Pada Perguruan Tinggi Berstatus BHMN.(Studi Penerapan
Teknologi Informasi pada FPEB Universitas Pendidikan Indonesia).

Malhotra, Yogesh \& Galetta, Dennis F., 1999, "Extending The Technology Acceptance Model to Account for Social Influence"

McLeod, Jr., Raymond, 2004. Sistem Informasi Manajemen. Edisi Kedelapan. Jakarta. Prenhallindo.

Nazir, Moch., 2003. Metode Penelitian. Jakarta. Ghalia Indonesia.

O'Brien, James A, 2002. Management Information System: Managing Information Technology in the EBusiness Erterprise, Fifth Edition. New York. McGraw-Hill Companies, Inc.

Oetomo, Dharma, Budi Sutedjo, etal. 2007. Pengantar Teknologi Informasi Internet, Konsep dan Aplikasi. Yogyakarta. Andi Offset.

Pallant, J 2005, SPSS survival manual: a step by step guide to data analysis using

SPSS 2 nd edn, Allen \& Unwin, Crows Nest, NSW.

Poerwadinata W. J. S. 1976. Kamus Umum Bahasa Imdonesia. Jakarta. Balai Pustaka.

Sugiyono, 2005. Metode Penelitian Kuantitatif, Kualitatif, dan $R \& D$. Bandung. Alfabeta. 